\title{
Report on FY 2020 Creep, Fatigue, and Creep-Fatigue Testing of Alloy 709 Base Metal at ORNL
}

Approved for public release. OAK RIDGE NATIONAL LABORATOR 를 MANAGED BY UT BATTELLE (2) FOR US. DEPARTMENT OF EAERGY

Distribution is unlimited.

Yanli Wang

Peijun Hou

T.-L. Sham

September 2020 


\title{
DOCUMENT AVAILABILITY
}

Reports produced after January 1, 1996, are generally available free via US Department of Energy (DOE) SciTech Connect.

Website www.osti.gov

Reports produced before January 1, 1996, may be purchased by members of the public from the following source:

\author{
National Technical Information Service \\ 5285 Port Royal Road \\ Springfield, VA 22161 \\ Telephone 703-605-6000 (1-800-553-6847) \\ TDD 703-487-4639 \\ Fax 703-605-6900 \\ E-mail info@ntis.gov \\ Website http://classic.ntis.gov/
}

Reports are available to DOE employees, DOE contractors, Energy Technology Data Exchange representatives, and International Nuclear Information System representatives from the following source:

Office of Scientific and Technical Information

PO Box 62

Oak Ridge, TN 37831

Telephone 865-576-8401

Fax 865-576-5728

E-mail reports@osti.gov

Website http://www.osti.gov/contact.html

This report was prepared as an account of work sponsored by an agency of the United States Government. Neither the United States Government nor any agency thereof, nor any of their employees, makes any warranty, express or implied, or assumes any legal liability or responsibility for the accuracy, completeness, or usefulness of any information, apparatus, product, or process disclosed, or represents that its use would not infringe privately owned rights. Reference herein to any specific commercial product, process, or service by trade name, trademark, manufacturer, or otherwise, does not necessarily constitute or imply its endorsement, recommendation, or favoring by the United States Government or any agency thereof. The views and opinions of authors expressed herein do not necessarily state or reflect those of the United States Government or any agency thereof. 
Materials Science and Technology Division

\title{
REPORT ON FY 2020 CREEP, FATIGUE, AND CREEP-FATIGUE TESTING OF ALLOY 709 BASE METAL AT ORNL
}

\author{
Yanli Wang \\ Peijun Hou* \\ T.-L. Sham ${ }^{\dagger}$
}

* University of Tennessee, Knoxville

$\uparrow$ Argonne National Laboratory

Date Published: September 2020

Prepared by

OAK RIDGE NATIONAL LABORATORY

Oak Ridge, TN 37831-6283

managed by

UT-BATTELLE, LLC

for the

US DEPARTMENT OF ENERGY

under contract DE-AC05-00OR22725 



\section{CONTENTS}

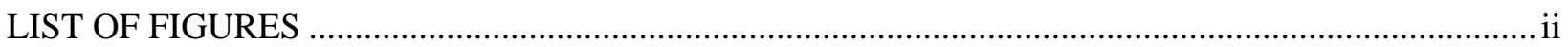

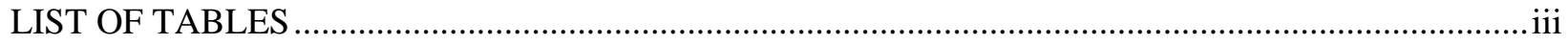

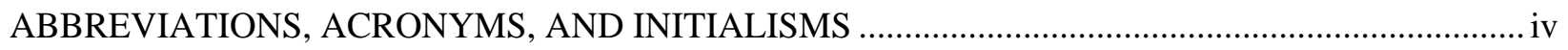

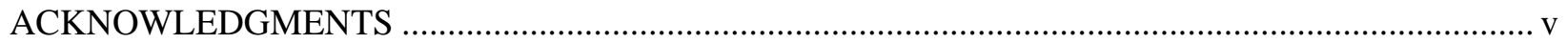

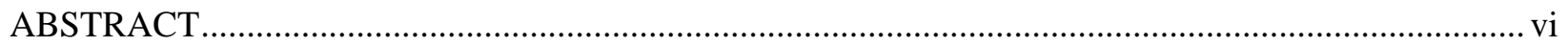

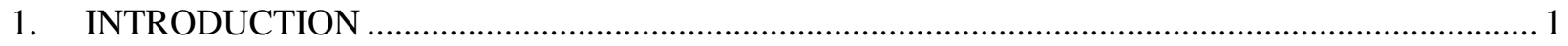

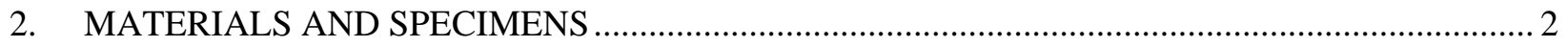

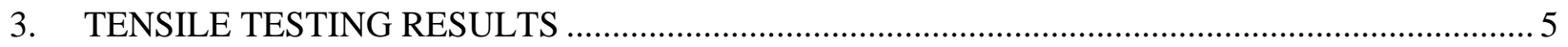

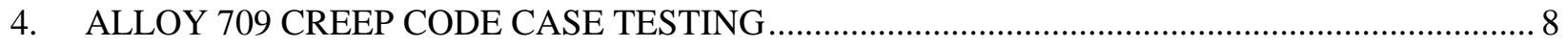

4.1 ORNL ALLOY 709 CREEP CODE CASE TESTING PLAN AND STATUS ....................... 8

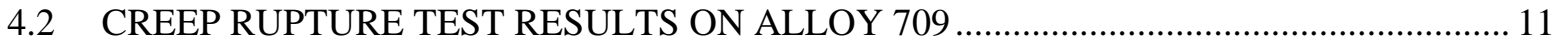

4.3 ADDITIONAL CONSIDERATIONS FOR CREEP RUPTURE TESTING ......................... 12

5. FATIGUE AND CREEP FATIGUE CODE CASE TESTING ON ALLOY 709 .......................... 13

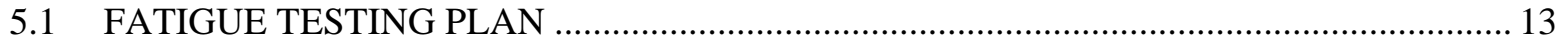

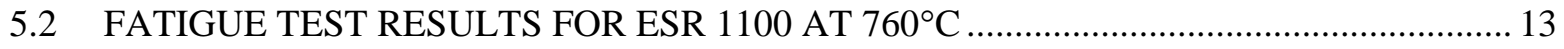

5.3 FATIGUE TEST RESULTS FOR HEAT-TREATED ESR 1150 AT 760 ${ }^{\circ} \mathrm{C} \ldots \ldots \ldots \ldots \ldots \ldots \ldots . . . . . . . . . . . . . .16$

5.4 PRELIMINARY FATIGUE DESIGN CURVE OF ALLOY 709 AT 760 ${ }^{\circ} \mathrm{C} \ldots \ldots \ldots \ldots \ldots \ldots \ldots . . . . . . . . . . . .17$

5.5 PRELIMINARY CREEP-FATIGUE TESTING PLAN ON ALLOY 709 ............................. 17

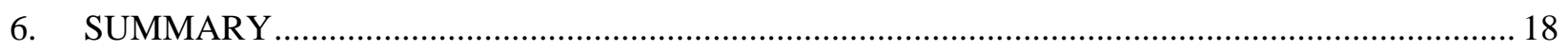

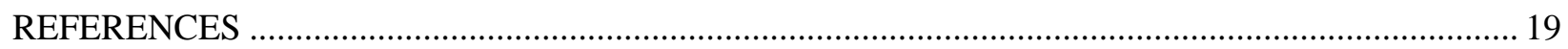




\section{LIST OF FIGURES}

Fig. 1. Tensile specimen geometry for Alloy 709 Code Case testing at ORNL.

Fig. 2. Standard fatigue and creep-fatigue specimen geometry for Alloy 709 Code Case testing at ORNL

Fig. 3. Creep specimen geometry for Alloy 709 Code Case testing at ORNL.

Fig. 4. Photographs of the as-received Alloy 709 specimens for tensile testing (a), creep testing

(b), and fatigue/creep-fatigue testing (c).

Fig. 5. Tensile stress-strain curves of heat-treated ESR 1150 (heat number 58776-3RBC)

Fig. 6. Comparison tensile stress-strain curves of as-annealed and heat-treated ESR 1150 at $550^{\circ} \mathrm{C}$ and $650^{\circ} \mathrm{C}$.

Fig. 7. Comparison of the tensile strength and yield strength of Alloy 709 (heat number 587763RBC) with those of Nippon Steel NF709, TP310MoCbN, Code Case data.

Fig. 8. Comparison of the tensile elongation of Alloy 709 (heat number 58776-3RBC) with that of Nippon Steel NF709, TP310MoCbN, Code Case data........................................................... 8

Fig. 9. Creep Code Case testing on Alloy 709 (heat number 58776-3RBB and 58776-4B). 8

Fig. 10. Plots of the rupture life (a) and minimum creep rate (MCR) (b) for the 18 creep tests on ESR 1100 (heat number 58776-3RBB) at ORNL

Fig. 11. Plots of the elongation (a) and reduction of area (b) for the 18 creep tests on ESR 1100 (heat number 58776-3RBB) at ORNL.

Fig. 12. Comparison of the ESR 1100 (heat number 58776-3RBB) creep rupture data with data for Nippon Steel NF709 on the LMP-stress plot.

Fig. 13. Strain-controlled fatigue loading profile for one cycle.

Fig. 14. Maximum and minimum stresses of fatigue tests on ESR 1100 (heat number 58776$3 \mathrm{RBB}$ ) at strain ranges of $3 \%$ (a), $2 \%$ (b), $1 \%$ (c), and $0.6 \%$ (d) at $760^{\circ} \mathrm{C}$.

Fig. 15. Maximum and minimum stresses of fatigue tests on ESR 1100 (heat number 587763RBB) at strain ranges of $0.4 \%$ (a), $0.3 \%$ (b), and $0.25 \%$ (c) at $760^{\circ} \mathrm{C}$.

Fig. 16. Maximum and minimum stresses of fatigue tests on heat-treated ESR 1150 (heat number $58776-3 \mathrm{RBC}$ ) at strain ranges of $3 \%(\mathrm{a}), 2 \%(\mathrm{~b}), 1 \%(\mathrm{c})$, and $0.6 \%(\mathrm{~d})$ at $760^{\circ} \mathrm{C}$.

Fig. 17. Preliminary fatigue design curve of Alloy 709 at $760^{\circ} \mathrm{C}$ 17 


\section{LIST OF TABLES}

Table 1. Chemical compositions of Alloy 709 with master heat number 58776 (wt \%).

Table 2. Tensile properties of Alloy 709 (heat number 58776-3RBC) after heat treatment at

$775^{\circ} \mathrm{C}$ for $10 \mathrm{~h}$

Table 3. Tensile properties of as-annealed Alloy 709 (heat number 58776-3RBC)............................... 7

Table 4. Creep Code Case testing matrix on Alloy 709 (heat number 58776-3RBB) .............................. 8

Table 5. Creep test status of Alloy 709 (heat number 58776-4B) at ORNL.......................................... 9

Table 6. Creep test status of Alloy 709 (heat number 58776-3RBB) at ORNL. .................................... 10

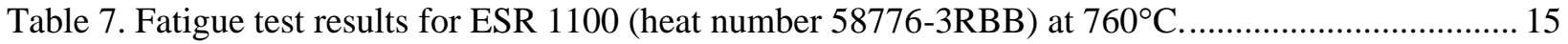

Table 8. Fatigue test results of heat-treated ESR 1150 (heat number 58776-3RBC) at $760^{\circ} \mathrm{C} \ldots \ldots \ldots \ldots \ldots . . . . . .17$

Table 9. Preliminary creep-fatigue test matrix for Alloy 709............................................................. 18 


\section{ABBREVIATIONS, ACRONYMS, AND INITIALISMS}

$\begin{array}{ll}\text { ANL } & \text { Argonne National Laboratory } \\ \text { AOD } & \text { argon-oxygen-decarburization } \\ \text { ART } & \text { Advanced Reactor Technologies } \\ \text { ASME } & \text { American Society of Mechanical Engineers } \\ \text { ASTM } & \text { American Society for Testing and Materials } \\ \text { CF } & \text { creep-fatigue } \\ \text { DOE } & \text { Department of Energy } \\ \text { ESR } & \text { electroslag remelt } \\ \text { INL } & \text { Idaho National Laboratory } \\ \text { LMP } & \text { Larson-Miller Parameter } \\ \text { MCR } & \text { minimum creep rate } \\ \text { NE } & \text { Office of Nuclear Energy } \\ \text { ORNL } & \text { Oak Ridge National Laboratory } \\ \text { SA } & \text { solution-annealing or solution-annealed } \\ \text { SFR } & \text { sodium fast reactor } \\ \text { RA } & \text { reduction of area } \\ \text { TC } & \text { thermocouple } \\ \text { UTS } & \text { ultimate tensile strength }\end{array}$




\section{ACKNOWLEDGMENTS}

This research was sponsored by the US Department of Energy (DOE), Office of Nuclear Energy (NE), under contract DE-AC05-00OR22725 with Oak Ridge National Laboratory (ORNL), managed and operated by UT-Battelle LLC. Programmatic direction was provided by the Office of Nuclear Reactor Deployment of DOE NE.

The authors gratefully acknowledge the support provided by Brian Robinson, DOE-NE, Federal Manager, Fast Reactors Campaign, Advanced Reactor Technologies (ART) Program; Sue Lesica, Federal Manager, Advanced Materials, ART Program; and Robert Hill of Argonne National Laboratory, National Technical Director, Fast Reactors Campaign, ART Program.

The authors also wish to thank ORNL staff members C. Shane Hawkins and Christina Padilla for their technical support in carrying out the experiments. The authors gratefully appreciate ORNL staff member Hong Wang for initiating the creep Code Case testing on Alloy 709. The time spent by Lianshan Lin, Jian Chen, and Edgar Lara-Curzio of ORNL reviewing this report is acknowledged. 


\begin{abstract}
The testing activities and research in support of ASME Code qualification of Alloy 709, an advanced austenitic steel, are being carried out at Oak Ridge National Laboratory (ORNL), Argonne National Laboratory, and Idaho National Laboratory. This report summarizes the status and results of FY 2020 planned testing at ORNL.

Uniaxial tensile tests on the electroslag remelt (ESR) solution-annealed plate (heat number 58776-3RBC) with additional heat treatment were performed for the baseline mechanical properties evaluation for ASME code qualification of Alloy 709. The tensile properties were found to meet ASME SA-213 specifications and were comparable to the Nippon Steel NF709 data generated for an ASME Section I Code Case for seamless tubing. ORNL was tasked to carry out a subset of the Code Case testing for creep rupture. Creep rupture data from 18 tests were generated on a solution-annealed ESR plate with a solution annealing temperature of $1100^{\circ} \mathrm{C}$. There are total of 19 intermediate and long-term creep rupture tests of Alloy 709 ongoing at ORNL. A preliminary fatigue design curve at $760^{\circ} \mathrm{C}$ was developed for Alloy 709 , and the results show that the fatigue design curve of Alloy 709 is comparable to that of Alloy $800 \mathrm{H}$ at $760^{\circ} \mathrm{C}$.
\end{abstract}




\section{INTRODUCTION}

Nuclear power contributes significantly to meeting the nation's energy, economic, environmental, and national security needs. The sodium fast reactor (SFR) is a leading candidate for recycling of used fuel to close the fuel cycle and for power generation. While SFR technology is relatively mature, there must be improvements in its capital cost and economic return before the private sector invests in large-scale, commercial deployment of SFRs. Advanced materials can have a significant impact on the flexibility, safety, and economics of future SFRs because innovative designs and design simplifications could be possible using materials with enhanced mechanical properties. Improved materials performance also impacts safety through improved reliability and greater design margins, and improved material reliability could result in reduced downtime. The objective of the Advanced Materials Development activities of the Advanced Reactor Technologies (ART) Program for the US Department of Energy Office of Nuclear Energy is to provide the technical basis needed to support the regulatory requirements for structural materials for advanced reactors that could be deployed in the near-term to mid-term by the US nuclear industry.

Because of significant enhancements in the mechanical properties of the austenitic stainless steel Alloy 709 relative to $316 \mathrm{H}$ stainless steel, a reference construction material for SFR systems, code qualification of Alloy 709 was recommended in FY 2014. A comprehensive plan was established in FY 2015 for the development of a $500,000 \mathrm{~h}, 760^{\circ} \mathrm{C}$ ASME Code Case and the resolution of structural integrity issues identified by the Nuclear Regulatory Commission for Alloy 709. The maximum use temperature of $760^{\circ} \mathrm{C}$ for the Alloy 709 Code Case has also drawn interest from molten salt reactor vendors and fluoride saltcooled high-temperature reactor developers. Completion of the Alloy 709 Code Case will allow US reactor vendors to decrease capital costs, expand design envelopes, and increase safety margins in the deployment of SFRs and other reactor concepts. Doing so will boost the competitiveness of the US advanced reactor sector, create high-paying jobs, and increase economic growth.

The execution of the Phase I plan was initiated in FY 2016. In collaboration with material vendor G.O. Carlson Inc. of Pennsylvania, the ART program successfully scaled up the production of Alloy 709 from a laboratory heat of $500 \mathrm{lb}$ to a commercial heat of 45,000 lb. The master heat of Alloy 709, heat number 58776, was processed under various conditions: (i) argon-oxygen-decarburization (AOD), (ii) half of the AOD was further electroslag remelted (ESR), and (iii) half of the ESR was subsequently homogenized (ESR-homogenized). Each type of ingot was hot-rolled into plates, which were then divided into three groups with each group given a solution-annealing (SA) treatment at different temperature. The fabrication procedures for the first commercial heat of Alloy 709 hot-rolled plates are summarized in Natesan et al. (2017). Meanwhile, creep-testing frames at Oak Ridge National Laboratory (ORNL) were upgraded or refurbished, and some new creep frames were procured at the Idaho National Laboratory (INL) and the Argonne National Laboratory (ANL), to support the generation of creep rupture data for the Alloy 709 Code Case.

The Alloy 709 plates produced under these different processing conditions were tested for creep, fatigue, and creep-fatigue under selected conditions to screen for the preferred processing condition. Both AOD with SA at $1100^{\circ} \mathrm{C}$ and ESR with SA at $1100^{\circ} \mathrm{C}$ showed good microstructure and combined hightemperature mechanical properties (McMurtrey 2018). The test effort for the comprehensive creep test matrix developed to support the preliminary, 100,000 h, 300,000 h, and 500,000 h Alloy 709 Code Cases was split among ANL, INL, and ORNL. In FY 2018, long-term creep tests were initiated at ORNL for plates produced by AOD SA at $1100^{\circ} \mathrm{C}$ with test temperatures from 550 to $800^{\circ} \mathrm{C}$ and stresses of 38 to $309 \mathrm{MPa}$, to a target rupture time of $60,000 \mathrm{~h}$ (Wang et al. 2018). In FY 2019, ESR with SA at $1100^{\circ} \mathrm{C}$ was added to the intermediate and long-term testing effort (Wang and Sham 2019). 
For high-temperature components, a material's ability to withstand combined cyclic loading and creep deformation is expected to be a critical aspect of its application. Baseline testing in the laboratory environment for evaluation of the high-temperature cyclic behaviors of a material involves standard continuous cycling or pure fatigue, and creep-fatigue (CF), in which a dwell time is introduced to the cyclic loading. Preliminary study of the fatigue and creep-fatigue behavior of Alloy 709 showed significant improvement in the CF life over the as-annealed condition after heat treatment at $775^{\circ} \mathrm{C}$ for $10 \mathrm{~h}$ (McMurtrey and Rupp 2019). The precipitates introduced in the microstructure by heat treatment played an important role in the enhanced CF performance (Zhang and Sham 2019). To achieve combined good creep resistance and CF performance, it was decided to include heat-treated ESR with SA at $1150^{\circ} \mathrm{C}$ in the Code Case test matrix.

This report documents the status of the planned FY 2020 creep and fatigue Code Case testing on ESR plates at ORNL. Uniaxial tensile tests were also performed and summarized as the baseline mechanical properties evaluation for the ASME code qualification of Alloy 709.

\section{MATERIALS AND SPECIMENS}

The chemical compositions of Alloy 709 with heat number 58776 are listed in Table 1. The ESR plates had a sub-heat number of 58776-3R, the plates with SA at $1100^{\circ} \mathrm{C}$ (ESR 1100) had a lot ID of 58776$3 \mathrm{RBB}$, and those with SA at $1150^{\circ} \mathrm{C}$ (ESR 1150) had a lot ID of 58776-3RBC. The nominal thickness of the ESR plates was $28.5 \mathrm{~mm}$. The Alloy 709 plates produced by AOD had a sub-heat number of 58776-4 and those with SA at $1100^{\circ} \mathrm{C}$ (AOD1100) had a lot ID of 58776-4B. The nominal thickness of the AOD plates was $30 \mathrm{~mm}$.

For comparison, the specifications for the chemical requirements of Nippon Steel NF709, TP310MoCbN, with a UNS number of S31025 in ASME SA-213 (ASME 2019a) are also listed in the Table 1. Alloy 709 with heat number 58776 in this study met the specified NF709 chemical requirements.

Table 1. Chemical compositions of Alloy 709 with master heat number 58776 (wt \%).

\begin{tabular}{|c|c|c|c|c|c|c|c|c|c|c|c|c|c|c|c|}
\hline $\begin{array}{l}\text { Heat or lot } \\
\text { ID }\end{array}$ & C & $\mathrm{Cr}$ & Co & $\mathbf{N i}$ & Mn & Mo & $\mathbf{N}$ & $\mathbf{S i}$ & $\mathbf{P}$ & $\mathbf{S}$ & $\mathbf{T i}$ & $\mathbf{N b}$ & Al & B & $\mathbf{C u}$ \\
\hline $\begin{array}{c}\text { 58776-3RBB; } \\
\text { or 58776- } \\
\text { 3RBC }\end{array}$ & 0.066 & 20.05 & 0.02 & 25.14 & 0.90 & 1.51 & 0.152 & 0.38 & 0.014 & 0.001 & 0.01 & 0.26 & 0.02 & 0.0030 & 0.06 \\
\hline 58776-4B & 0.07 & 19.93 & 0.02 & 24.98 & 0.91 & 1.51 & 0.148 & 0.44 & 0.014 & $<.000$ & 0.04 & 0.26 & 0.02 & 0.0045 & 0.06 \\
\hline UNS-S31025 & $\begin{array}{l}0.10 \\
\max \end{array}$ & $\begin{array}{l}19.0- \\
23.0\end{array}$ & - & $\begin{array}{l}22.0- \\
28.0 \\
\end{array}$ & $\begin{array}{l}1.50 \\
\max \end{array}$ & $\begin{array}{l}1.0- \\
2.0 \\
\end{array}$ & $\begin{array}{l}0.10- \\
0.25 \\
\end{array}$ & $\begin{array}{l}1.00 \\
\max \end{array}$ & $\begin{array}{l}0.030 \\
\max \\
\end{array}$ & $\begin{array}{l}0.010 \\
\max \\
\end{array}$ & $\begin{array}{l}0.20 \\
\max \end{array}$ & $\begin{array}{l}0.10- \\
0.40 \\
\end{array}$ & - & $\begin{array}{l}0.002- \\
0.010 \\
\end{array}$ & - \\
\hline $\begin{array}{cc}\text { Note: } & \\
\text { 1. } & \text { Bal } \\
\text { 2. } & 587 \\
\text { 3. } & 587\end{array}$ & $\begin{array}{l}\text { is } \\
\mathrm{RB} \\
\mathrm{B} \text { i }\end{array}$ & 70 & D & A & 110 & D & $\begin{array}{l}100) \text {, } \\
00) .\end{array}$ & 58 & $\mathrm{RB}$ & Allo & $\mathrm{E}$ & ith & 15 & ESR & \\
\hline
\end{tabular}

An additional heat treatment of the ESR plate with SA at $1150^{\circ} \mathrm{C}$ (ESR 1150) was performed to ensure an optimized creep and creep-fatigue performance. The heat treatment was at $775^{\circ} \mathrm{C}$ for $10 \mathrm{~h}$ in air followed by air cooling.

The specimen geometries for uniaxial tensile, fatigue, and creep Code Case testing are shown in Fig. 1, Fig. 2, and Fig. 3, respectively. The tensile specimen has a nominal diameter of $6.35 \mathrm{~mm}$ and gage length of $31.75 \mathrm{~mm}$. The standard fatigue or creep-fatigue specimen has a gage diameter of $6.35 \mathrm{~mm}$ and a 19.05 $\mathrm{mm}$ gage length. The creep specimen was designed to have a $9.53 \mathrm{~mm}$ gage diameter with a nominal gage length of $47.63 \mathrm{~mm}$. Note that the larger-than-normal $6.35 \mathrm{~mm}$ diameter creep specimen geometry was used to reduce the oxidation effect during long-term creep testing. All the Code Case testing specimens 
were machined from the mid-thickness of the Alloy 709 plates along the rolling direction. Photographs of the as-received Alloy 709 test specimens are presented in Fig. 4.

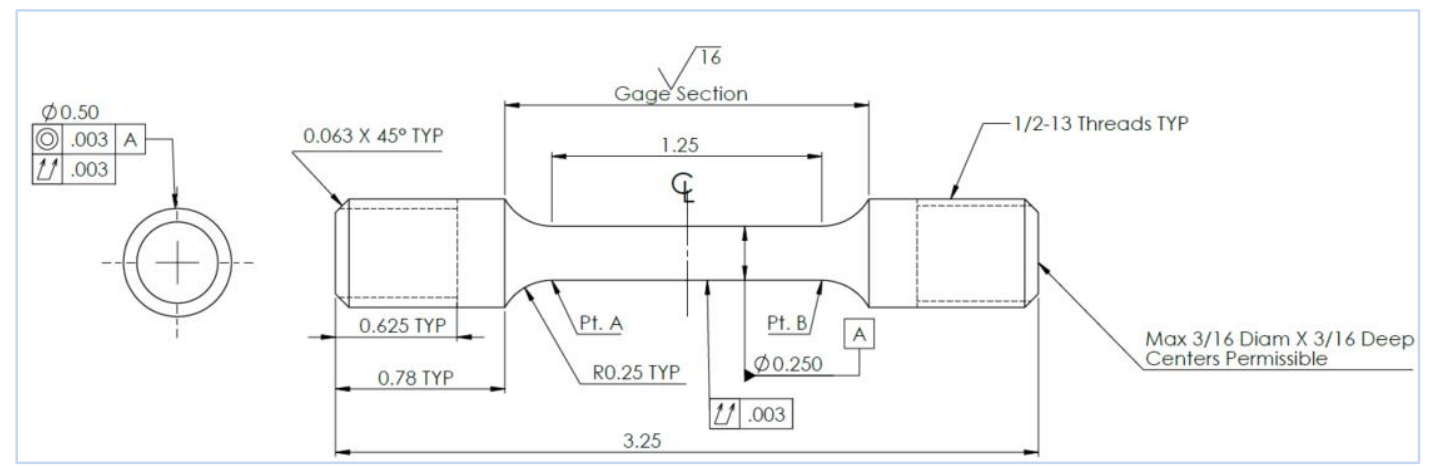

Fig. 1. Tensile specimen geometry for Alloy 709 Code Case testing at ORNL. Dimensions are in inches.

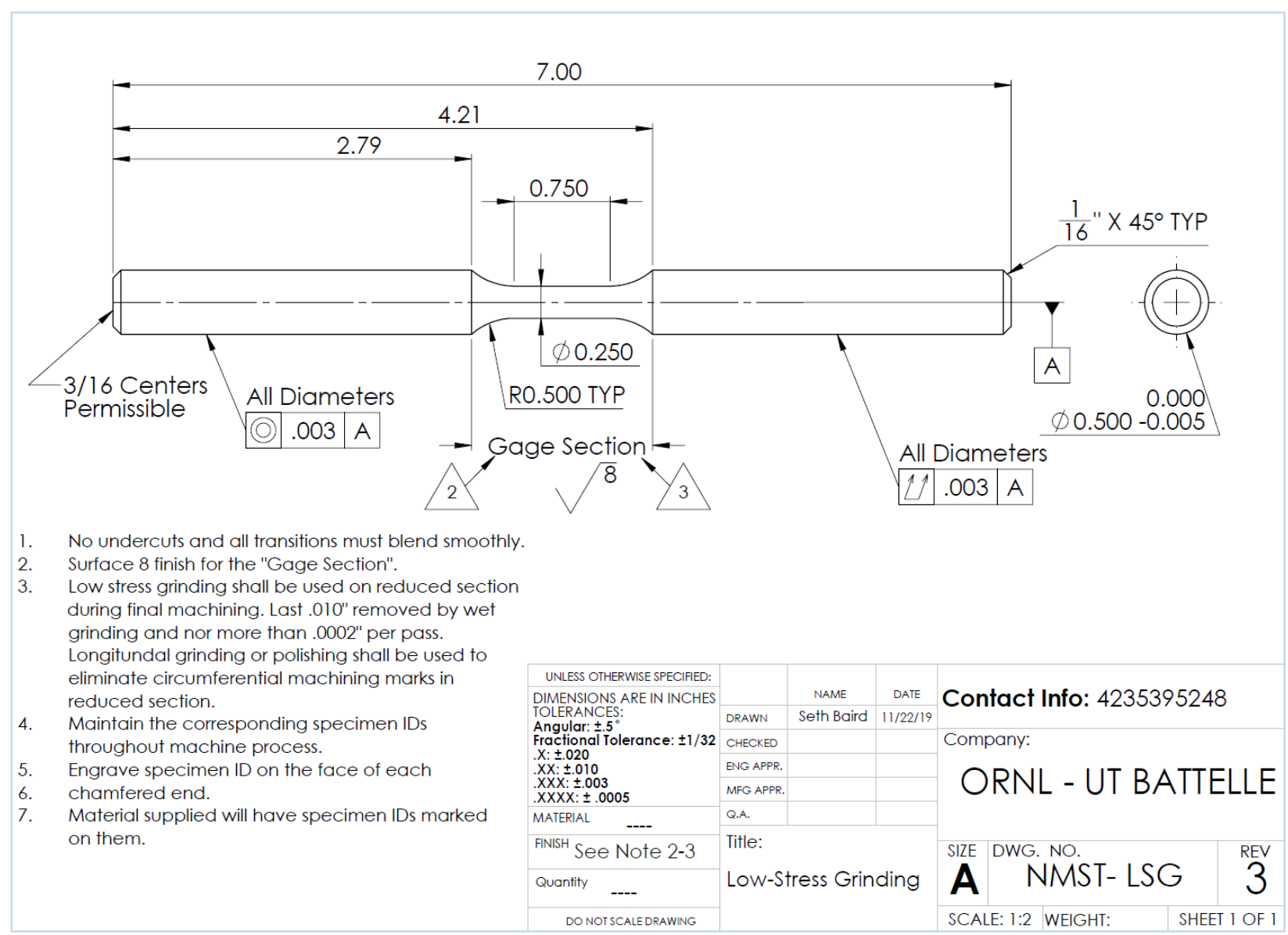

Fig. 2. Standard fatigue and creep-fatigue specimen geometry for Alloy 709 Code Case testing at ORNL.

Dimensions are in inches. 


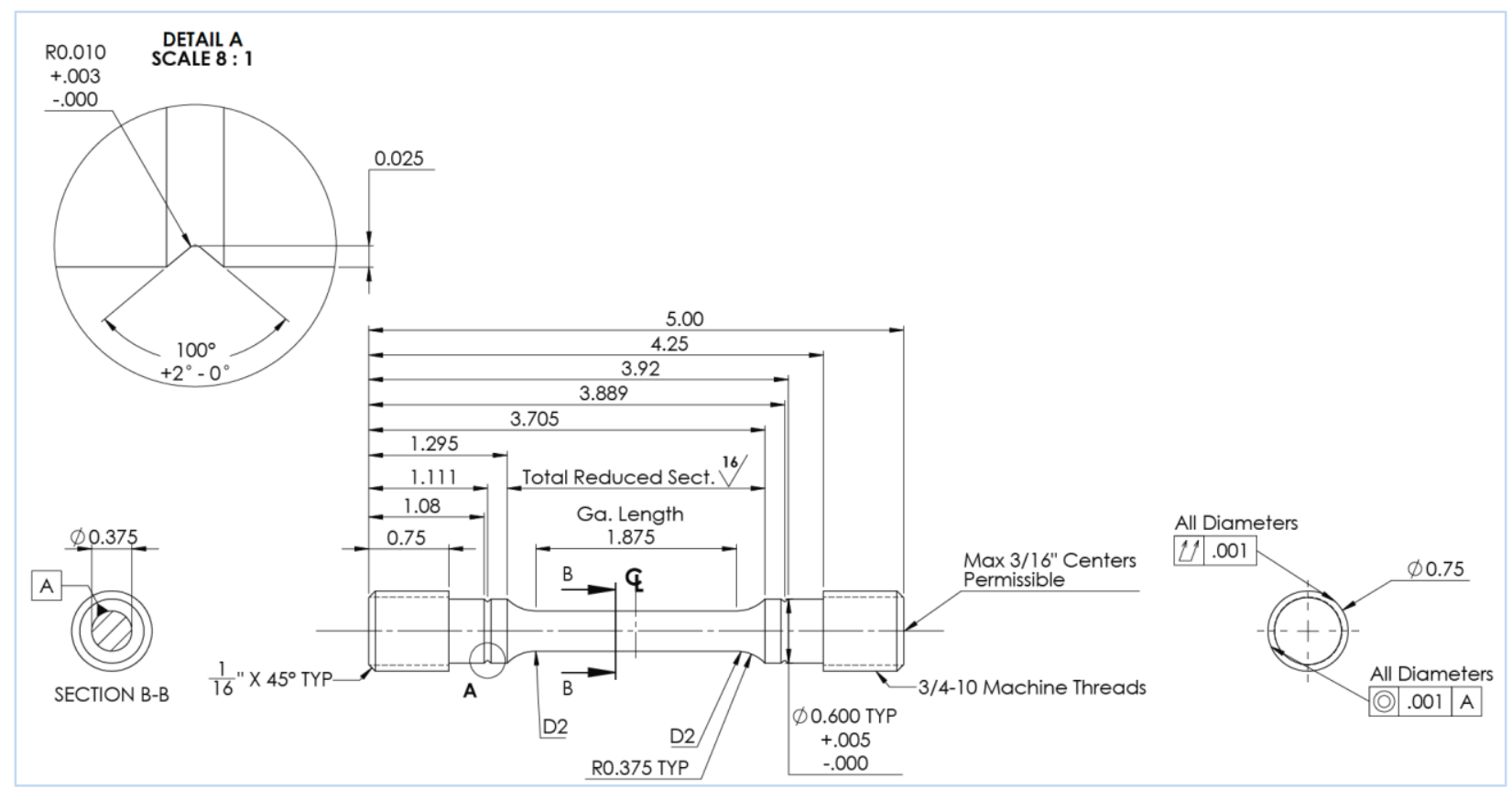

Fig. 3. Creep specimen geometry for Alloy 709 Code Case testing at ORNL. Dimensions are in inches.

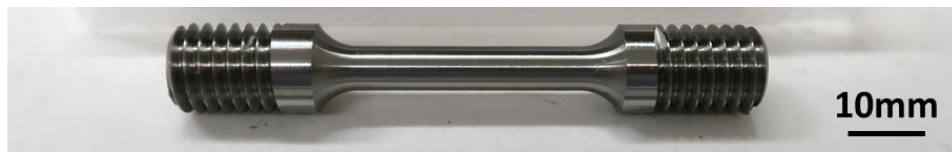

(a)

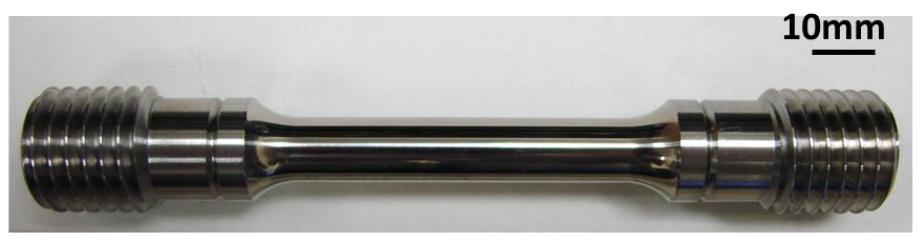

(b)

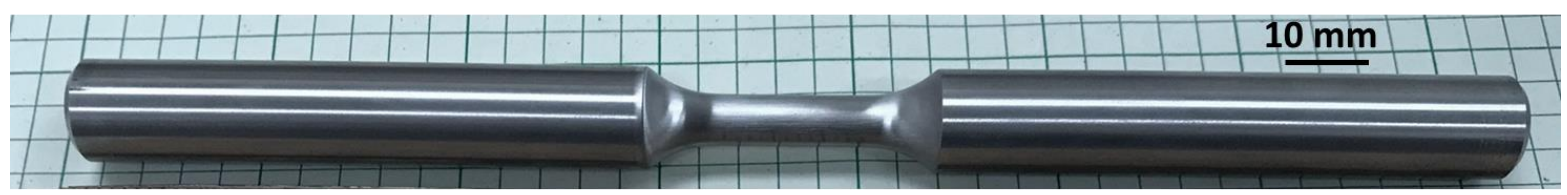

(c)

Fig. 4. Photographs of the as-received Alloy 709 specimens for tensile testing (a), creep testing (b), and fatigue/creep-fatigue testing (c). 


\section{TENSILE TESTING RESULTS}

After heat treatment at $775^{\circ} \mathrm{C}$ for $10 \mathrm{~h}$, the mechanical properties of ESR 1150 (heat number 58776$3 \mathrm{RBC}$ ) were evaluated to ensure its room-temperature and high-temperature tensile properties met code specifications. Tensile testing was performed under displacement control from room temperature to $950^{\circ} \mathrm{C}$ according to ASTM standard test methods ASTM E8-16 and ASTM E21-17.

The tensile stress-strain curves for all test temperatures are presented in Fig. 5. Note that at the intermediate temperature range of $500-625^{\circ} \mathrm{C}$, serrated stress-strain curves, i.e., the Portevin-Le Chatelier effect, are observed. This effect is associated with dynamic strain aging. At temperatures above $625^{\circ} \mathrm{C}$, the total elongation increases with the increase in test temperature. All tests showed ductile tensile behavior. The measured tensile properties - including yield strength, ultimate tensile strength (UTS), uniform tensile strain, total elongation, and reduction of area-are tabulated in Table 2. At room temperature, ASME SA-213 specifications for Nippon Steel NF709, TP310MoCbN, require a minimum tensile strength of $640 \mathrm{MPa}$, minimum yield strength of $270 \mathrm{MPa}$, and minimum elongation of $30 \%$ (ASME 2019a). The two duplicates at room temperature exceed all the Code-specified minimum properties. Above a temperature of $550^{\circ} \mathrm{C}$, the uniform tensile strain, i.e., the strain to UTS, decreases with increasing test temperature, although the total elongation increases.

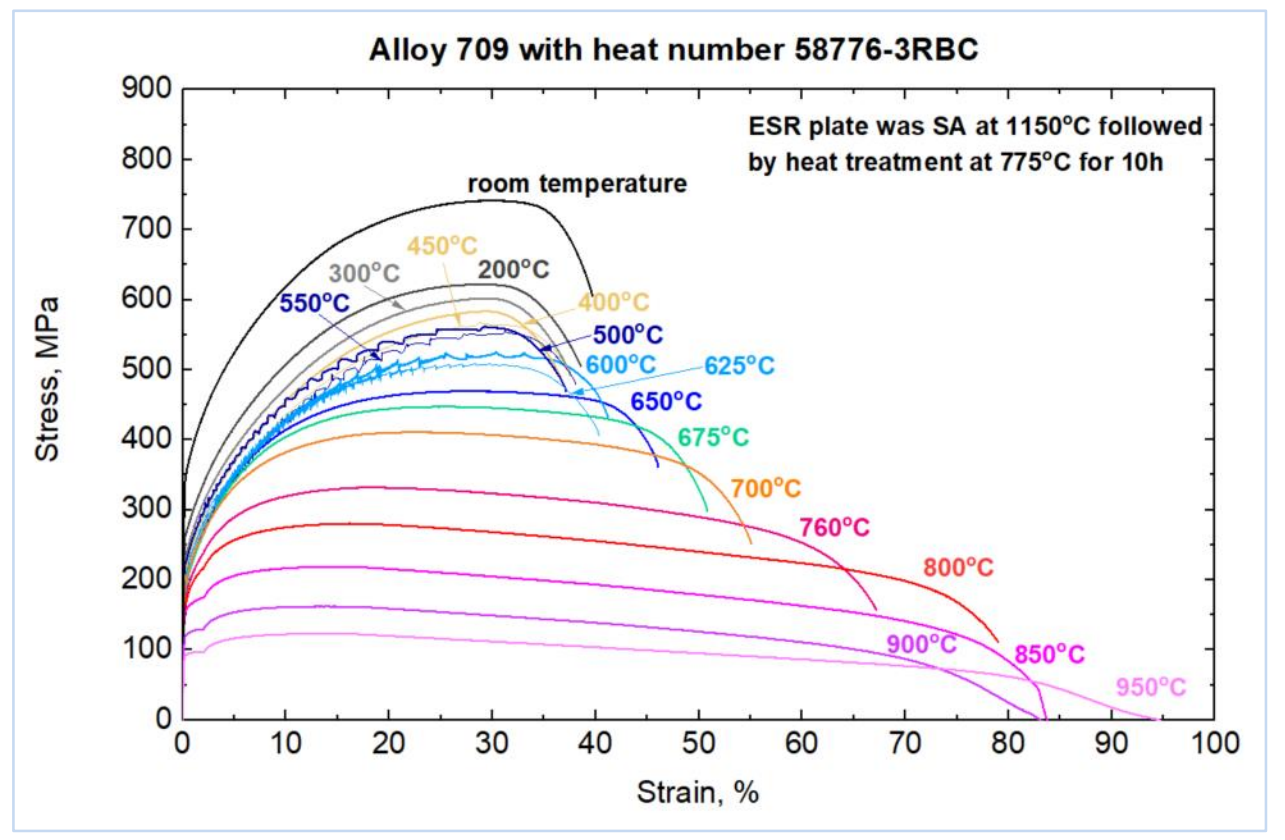

Fig. 5. Tensile stress-strain curves of heat-treated ESR 1150 (heat number 58776-3RBC).

Tensile properties of the as-annealed ESR 1150 were also evaluated at $550^{\circ} \mathrm{C}$ and $650^{\circ} \mathrm{C}$. The stressstrain curves are plotted in Fig. 6 and compared with those of the heat-treated specimens. Table 3 summarizes the tensile properties at these two temperatures, along with those at room temperature, on specimens along both the rolling direction and the transverse direction reported by Natesan et al. (2017). The results show that at room temperature, heat treatment increases the yield strength and UTS without a significantly reduction in ductility. At higher test temperatures of $550^{\circ} \mathrm{C}$ and $650^{\circ} \mathrm{C}$, the UTS is slightly decreased, although the yield strength is increased by the heat treatment, and the elongation remains the same as in the as-annealed condition. 
Table 2. Tensile properties of Alloy 709 (heat number 58776-3RBC) after heat treatment at $775^{\circ} \mathrm{C}$ for $10 \mathrm{~h}$.

\begin{tabular}{l|l|l|l|l|l|l}
\hline Specimen ID & \multicolumn{1}{|c|}{$\begin{array}{c}\text { Temperature } \\
\left({ }^{\circ} \mathbf{C}\right)\end{array}$} & $\begin{array}{c}\text { Yield } \\
\text { strength } \\
(\mathbf{M P a})\end{array}$ & $\begin{array}{c}\text { UTS } \\
(\mathbf{M P a})\end{array}$ & $\begin{array}{c}\text { Uniform } \\
\text { strain } \\
(\boldsymbol{\%})\end{array}$ & $\begin{array}{c}\text { Total } \\
\text { elongation } \\
(\boldsymbol{\%})\end{array}$ & $\begin{array}{c}\text { Reduction } \\
\text { of area } \\
(\%)\end{array}$ \\
\hline BCHT_OT_29-01 & Room temperature, $23^{\circ} \mathrm{C}$ & 358.8 & 747.1 & 26.3 & 39.8 & 52.6 \\
\hline BCHT_OT_54-02 & Room temperature, $23^{\circ} \mathrm{C}$ & 367.3 & 747.5 & 26.4 & 39.8 & 52.9 \\
\hline BCHT_OT_53-06 & 200 & 273.0 & 626.8 & 29.1 & 38.7 & 46.5 \\
\hline BCHT_OT_49-07 & 300 & 240.0 & 605.6 & 29.6 & 37.6 & 45.3 \\
\hline BCHT_OT_45-08 & 400 & 224.3 & 588.3 & 29.4 & 36.7 & 46.1 \\
\hline BCHT_OT_26-09 & 450 & 210.0 & 571.3 & 28.8 & 37.5 & 39.4 \\
\hline BCHT_OT_41-10 & 500 & 229.3 & 564.7 & 29.3 & 37.1 & 42.6 \\
\hline BCHT_OT_47-11 & 550 & 201.9 & 561.6 & 31.2 & 38.1 & 41.2 \\
\hline BCHT_OT_25-04 & 600 & 210.2 & 530.1 & 30.4 & 41.2 & 41.9 \\
\hline BCHT_OT_44-12 & 625 & 209.0 & 513.8 & 28.4 & 40.3 & 47.6 \\
\hline BCHT_OT_22-03 & 650 & 200.4 & 474.0 & 28.1 & 46.1 & 55.0 \\
\hline BCHT_OT_33-13 & 675 & 196.2 & 452.1 & 25.2 & 50.8 & 57.3 \\
\hline BCHT_OT_30-14 & 700 & 201.2 & 414.3 & 22.2 & 55.0 & 62.5 \\
\hline BCHT_OT_46-05 & 760 & 184.5 & 336.3 & 18.5 & 67.3 & 75.8 \\
\hline BCHT_OT_48-15 & 800 & 172.9 & 284.9 & 16.2 & 79.4 & 81.5 \\
\hline BCHT_OT_35-16 & 850 & 160.5 & 223.6 & 15.1 & 83.7 & 87.1 \\
\hline BCHT_OT_38-17 & 900 & 126.3 & 167.3 & 14.2 & 83.1 & 95.5 \\
\hline BCHT_OT_34-18 & 950 & 96.5 & 127.2 & 14.3 & 94.5 & 95.4 \\
\hline
\end{tabular}

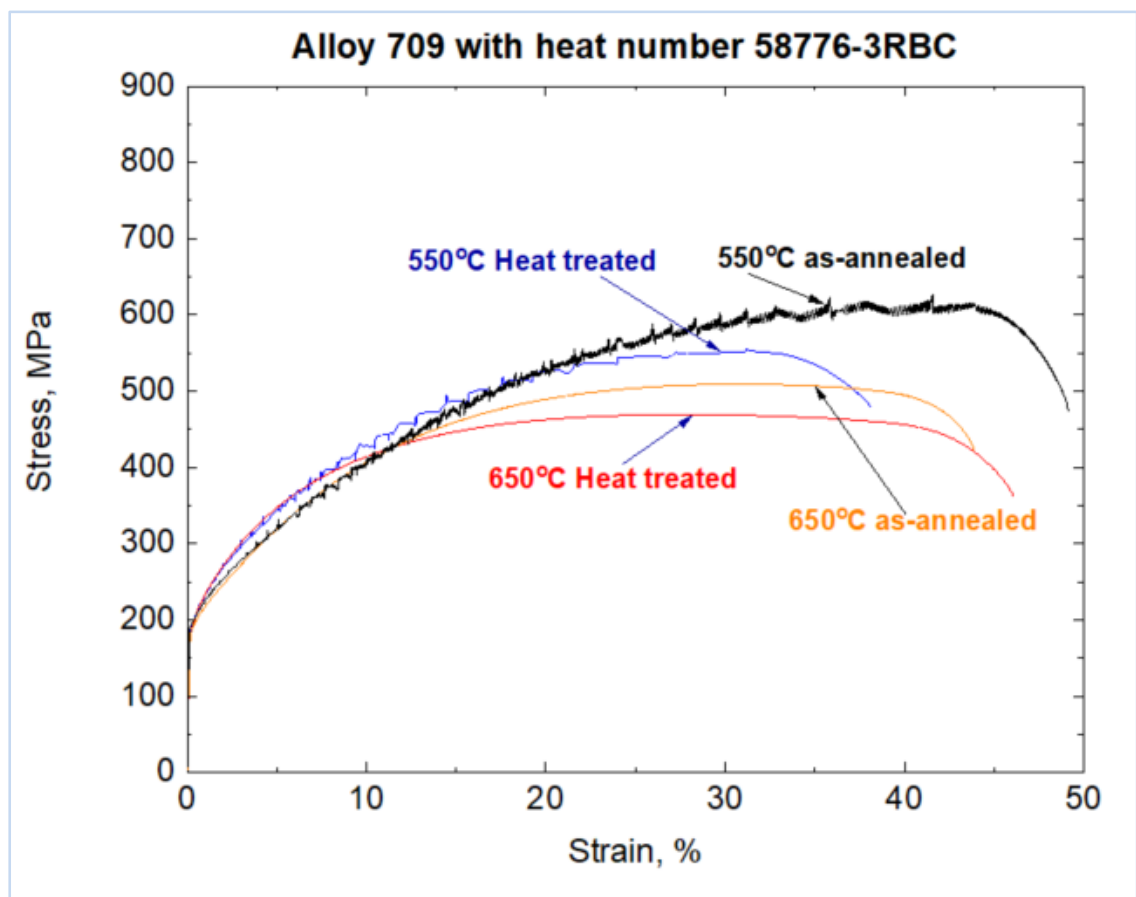

Fig. 6. Comparison tensile stress-strain curves of as-annealed and heat-treated ESR 1150 at $550^{\circ} \mathrm{C}$ and $650^{\circ} \mathrm{C}$. 
Table 3. Tensile properties of as-annealed Alloy 709 (heat number 58776-3RBC).

\begin{tabular}{c|l|l|l|l|l}
\hline $\begin{array}{c}\text { Temperature } \\
\left({ }^{\circ} \mathbf{C}\right)\end{array}$ & $\begin{array}{c}\text { Yield strength } \\
(\mathbf{M P a})\end{array}$ & $\begin{array}{c}\text { UTS } \\
(\mathbf{M P a})\end{array}$ & $\begin{array}{c}\text { Uniform strain, } \\
(\boldsymbol{\%})\end{array}$ & $\begin{array}{c}\text { Total } \\
\text { elongation } \\
(\mathbf{\%})\end{array}$ & $\begin{array}{c}\text { Reduction } \\
\text { of area } \\
(\boldsymbol{\%})\end{array}$ \\
\hline $\begin{array}{c}\text { Room temperature, } 23^{\circ} \mathrm{C} \\
\text { (rolling direction) }\end{array}$ & 287.1 & 664.4 & - & 48.9 & 72.4 \\
\hline $\begin{array}{c}\text { Room temperature, } 23^{\circ} \mathrm{C} \\
\text { (transverse direction) }\end{array}$ & 325.0 & 694.1 & - & 44.1 & 70.4 \\
\hline 550 & 197.6 & 626.4 & 41.6 & 49.1 & 49.0 \\
\hline 650 & 191.9 & 509.1 & 30.9 & 43.8 & 42.6 \\
\hline
\end{tabular}

The yield strength and tensile strength of ESR 1150 are compared with those of Nippon Steel NF709, TP310MoCbN, Code Case data in Fig. 7. In this figure, $R_{Y}, R_{T}, S_{Y}$ and $S_{T}$ are from the Nippon Steel NF709 Code Case, where $R_{Y}$ and $R_{T}$ are the ratios of the average temperature-dependent trend curve values of yield strength and tensile strength to the room-temperature yield strength and tensile strength. The $S_{Y}$ and $S_{T}$ are the specified minimum values of yield strength and tensile strength, respectively, at room temperature. The tensile elongation of ESR 1150 is compared with that of Nippon Steel NF709, TP310MoCbN, Code Case data in Fig. 8. Both as-annealed and heat-treated Alloy 709 (heat number 58776-3RBC) exceed the minimum room-temperature tensile properties specified by SA-213(ASME 2019a), which are based on Nippon Steel NF709 Code Case data. The yield strength is comparable to the average Nippon Steel NF709 code case data at all temperatures. At temperatures below $650^{\circ} \mathrm{C}$, the tensile strength is consistent with the average value; and the elongation of the heat-treated ESR 1150 is at the lower bound of the Nippon Steel NF709 Code Case data. Above $650^{\circ} \mathrm{C}$, the tensile strength trends down to the lower bound consistently, and the elongation is at the higher bound of the Nippon Steel NF709 Code Case data.

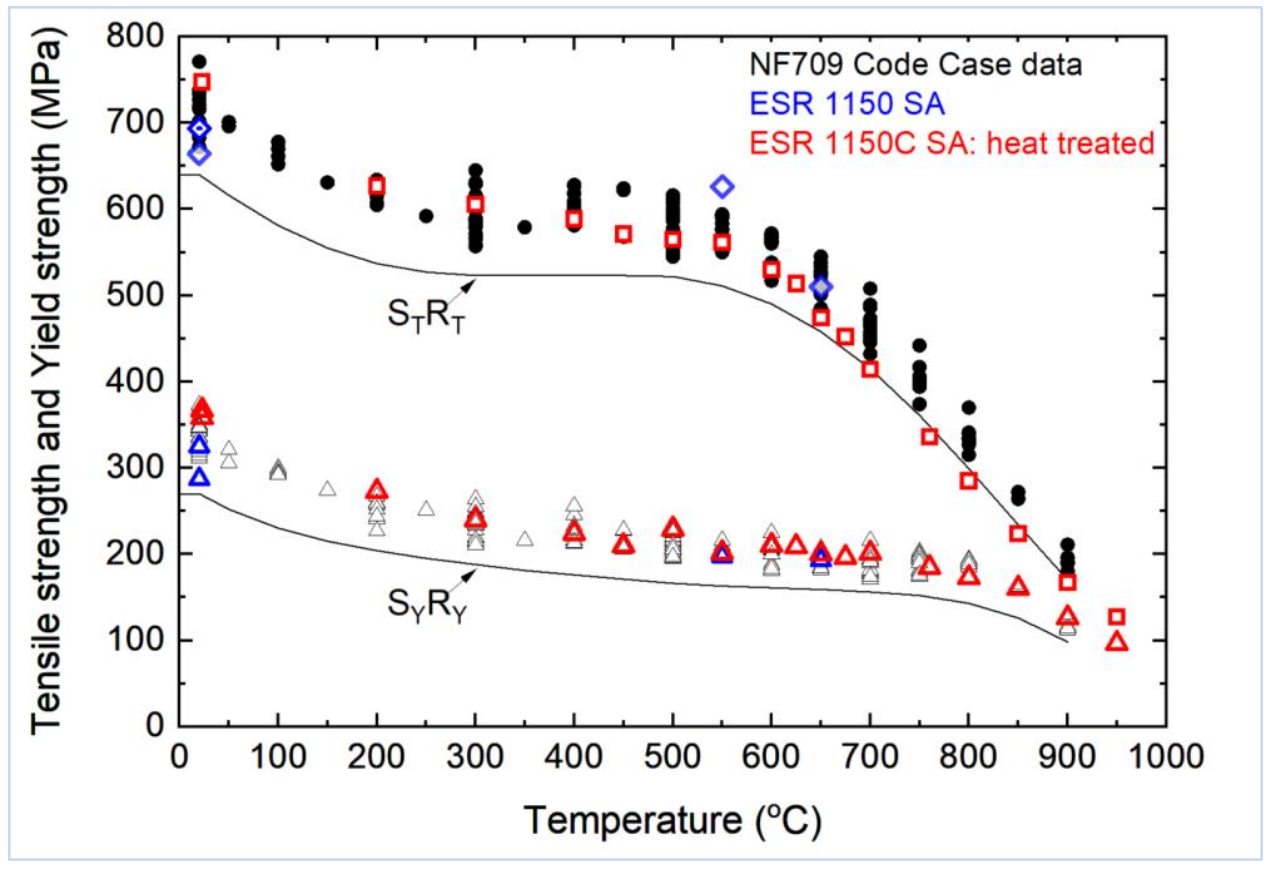

Fig. 7. Comparison of the tensile strength and yield strength of Alloy 709 (heat number 58776-3RBC) with those of Nippon Steel NF709, TP310MoCbN, Code Case data. 


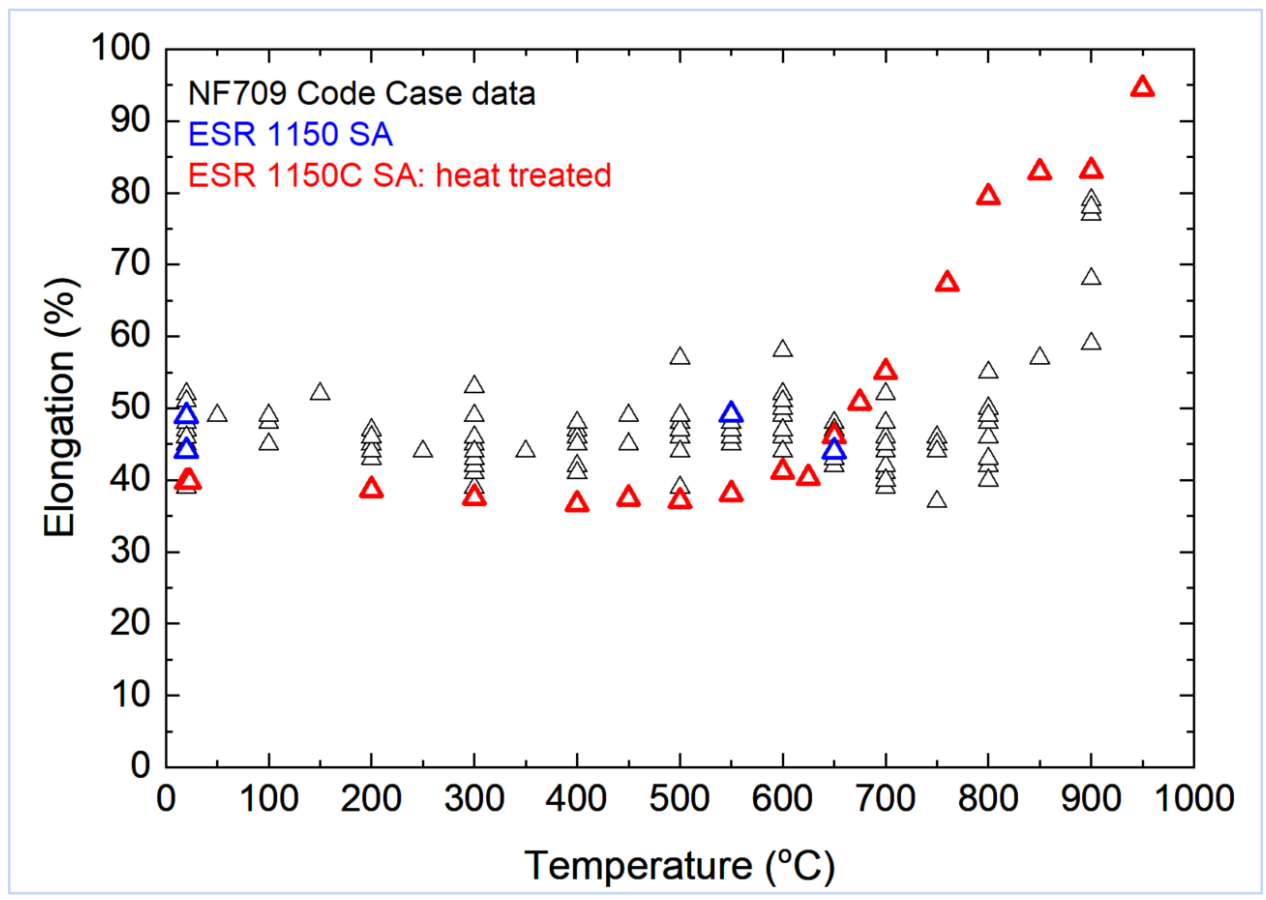

Fig. 8. Comparison of the tensile elongation of Alloy 709 (heat number 58776-3RBC) with that of Nippon Steel NF709, TP310MoCbN, Code Case data.

\section{ALLOY 709 CREEP CODE CASE TESTING}

\subsection{ORNL ALLOY 709 CREEP CODE CASE TESTING PLAN AND STATUS}

A comprehensive master creep testing matrix for Alloy 709 Code Case testing was generated which involved a total of 69 creep test conditions of ESR with SA at $1100^{\circ} \mathrm{C}$ (ESR 1100, heat number 587763RBB). The testing activities and research to support the qualification of Alloy 709 were carried out at ANL, INL, and ORNL. The creep testing matrix was used to generate data to support the development of preliminary, 100,000 h, 300,000 h, and 500,000 h Code Cases. The creep Code Case testing matrix is summarized in Table 4 . The creep Code Case testing covers a temperature range of $525-950^{\circ} \mathrm{C}$ and stress levels of 15-380 MPa; these testing conditions are plotted in Fig. 9.

Table 4. Creep Code Case testing matrix on Alloy 709 (heat number 58776-3RBB).

\begin{tabular}{c|c|c|c|c}
\hline $\begin{array}{c}\text { Target } \\
\text { Code Case }\end{array}$ & $\begin{array}{c}\text { Target rupture life } \\
(\mathbf{h})\end{array}$ & $\begin{array}{c}\text { Temperature } \\
\left({ }^{\circ} \mathbf{C}\right)\end{array}$ & $\begin{array}{c}\text { Stress } \\
(\mathbf{M P a})\end{array}$ & $\begin{array}{c}\text { Labs } \\
\text { involved }\end{array}$ \\
\hline Preliminary & $500-10,000$ & $575-950$ & $21-355$ & $\begin{array}{c}\text { Argonne/INL/ } \\
\text { ORNL }\end{array}$ \\
\hline $100,000 \mathrm{~h}$ & $11,000-24,000$ & $550-950$ & $15-380$ & Argonne/INL \\
\hline $300,000 \mathrm{~h}$ & $25,000-68,000$ & $550-925$ & $15-330$ & ORNL \\
\hline $500,000 \mathrm{~h}$ & $91,000-109,000$ & $525-800$ & $35-355$ & ORNL \\
\hline
\end{tabular}


ORNL has been tasked to carry out a subset of the creep Code Case testing matrix of ESR 1100 and AOD 1100; these testing conditions are also shown in Fig. 9 with colored symbols. The creep Code Case testing at ORNL was started in FY 2019 with a total of 31 creep tests on ESR 1100 and 6 long-term tests on AOD 1100. The testing procedure followed ASTM E 139-11, Standard Test Methods for Conducting Creep, Creep-Rupture, and Stress-Rupture Tests of Metallic Materials. The creep tests were arranged to best utilize the individual creep machine capacity and estimated testing duration.

At the time of this report, 18 test specimens of ESR 1100 under a total of 17 conditions had ruptured (one duplicate rupture test was at $600^{\circ} \mathrm{C}$ and $330 \mathrm{MPa}$ ). Most of the short-term rupture data were documented in Wang and Sham (2019). Currently, there are 13 creep tests running on ESR 1100 along with the 6 long-term tests on AOD 1100. The creep test conditions and status of the AOD 1100 specimens are in listed in Table 5, and the 31 creep tests on ESR 1100 are summarized in Table 6.

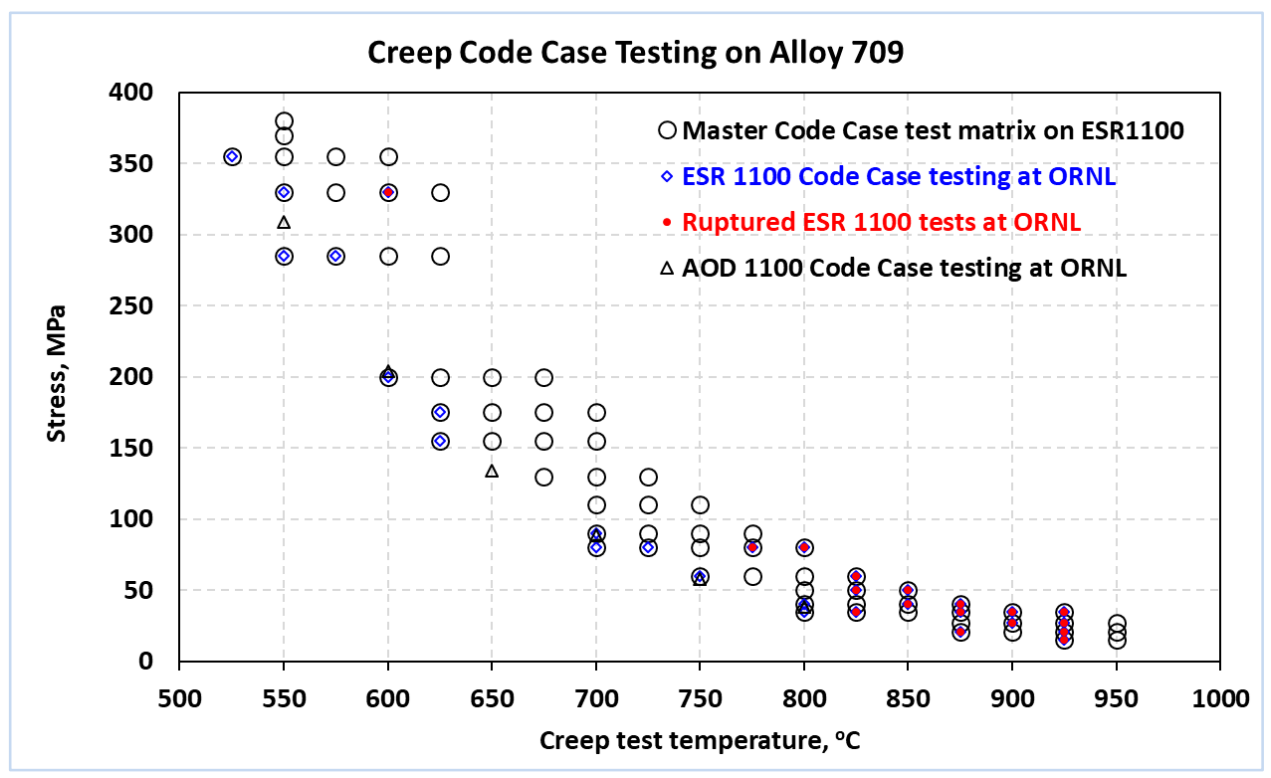

Fig. 9. Creep Code Case testing on Alloy 709 (heat number 58776-3RBB and 58776-4B).

Table 5. Creep test status of Alloy 709 (heat number 58776-4B) at ORNL.

\begin{tabular}{l|l|l|l|l|l}
\hline Test number & $\begin{array}{c}\text { Creep } \\
\text { frame } \\
\text { number }\end{array}$ & $\begin{array}{c}\text { Stress } \\
(\mathbf{M P a})\end{array}$ & $\begin{array}{c}\text { Temperature } \\
\left({ }^{\circ} \mathbf{C}\right)\end{array}$ & $\begin{array}{c}\text { Thermocouple } \\
\text { type }\end{array}$ & Status \\
\hline 33629 & 88 & 309 & 550 & $\mathrm{~K}$ & Ongoing \\
\hline 33630 & 93 & 204 & 600 & $\mathrm{~K}$ & Ongoing \\
\hline 33631 & 91 & 134 & 650 & $\mathrm{~K}$ & Ongoing \\
\hline 33632 & 95 & 88 & 700 & $\mathrm{~K}$ & Ongoing \\
\hline 33635 & 302 & 38 & 800 & $\mathrm{~K}$ & Ongoing \\
\hline 33636 & 303 & 58 & 750 & $\mathrm{~K}$ & Ongoing \\
\hline
\end{tabular}


Table 6. Creep test status of Alloy 709 (heat number 58776-3RBB) at ORNL.

\begin{tabular}{|c|c|c|c|c|c|}
\hline Test number & $\begin{array}{c}\text { Creep } \\
\text { frame } \\
\text { number }\end{array}$ & $\begin{array}{l}\text { Stress } \\
(\mathrm{MPa})\end{array}$ & $\begin{array}{c}\text { Temperature } \\
\left({ }^{\circ} \mathbf{C}\right)\end{array}$ & $\begin{array}{c}\text { Thermocouple } \\
\text { type }\end{array}$ & Status \\
\hline 34162 & 5 & 355 & 525 & $\mathrm{~K}$ & Ongoing \\
\hline 34163 & 6 & 330 & 550 & $\mathrm{~K}$ & Ongoing \\
\hline 34182 & 516 & 285 & 550 & $\mathrm{~K}$ & Ongoing \\
\hline 34183 & 517 & 285 & 575 & $\mathrm{~K}$ & Ongoing \\
\hline 34130 & 94 & 200 & 600 & $\mathrm{~K}$ & Ongoing \\
\hline 34110 & 307 & 175 & 625 & $\mathrm{~K}$ & Ongoing \\
\hline 34113 & 306 & 155 & 625 & $\mathrm{~K}$ & Ongoing \\
\hline 34111 & 305 & 90 & 700 & $\mathrm{~K}$ & Ongoing \\
\hline 34161 & 301 & 80 & 700 & $\mathrm{~K}$ & Ongoing \\
\hline 34112 & 304 & 80 & 725 & $\mathrm{~K}$ & Ongoing \\
\hline 34133 & 78 & 80 & 775 & $\mathrm{~K}$ & Ruptured \\
\hline 34132 & 80 & 80 & 800 & $\mathrm{~S}$ & Ruptured \\
\hline 34184 & 518 & 60 & 750 & K & Ongoing \\
\hline 34131 & 81 & 60 & 825 & $\mathrm{~S}$ & Ruptured \\
\hline 34160 & 64 & 50 & 850 & K & Ruptured \\
\hline 34241 & 511 & 40 & 800 & $\mathrm{~K}$ & Ongoing \\
\hline 34181 & 510 & 40 & 875 & $\mathrm{~K}$ & Ruptured \\
\hline 34265 & 64 & 35 & 800 & $\mathrm{~K}$ & Ongoing \\
\hline 35002 & 77 & 35 & 825 & $S$ & Ruptured \\
\hline 34244 & 80 & 35 & 875 & $\mathrm{~S}$ & Ruptured \\
\hline 34278 & 83 & 35 & 900 & $\mathrm{~S}$ & Ruptured \\
\hline 34277 & 79 & 35 & 925 & $\mathrm{~S}$ & Ruptured \\
\hline 34242 & 81 & 27 & 925 & $S$ & Ruptured \\
\hline 34274 & 76 & 21 & 875 & $\mathrm{~S}$ & Ruptured \\
\hline 34275 & 77 & 15 & 925 & $\mathrm{~S}$ & Ruptured \\
\hline 34245 & 89 & 50 & 825 & $\mathrm{~K}$ & Ruptured \\
\hline 35004 & 79 & 40 & 850 & $S$ & Ruptured \\
\hline 35061 & 80 & 27 & 900 & $S$ & Ruptured \\
\hline 35062 & 81 & 21 & 925 & $S$ & Ruptured \\
\hline 33265 & 88 & 300 & 600 & $\mathrm{~K}$ & Ruptured \\
\hline 33563 & 7 & 300 & 600 & $\mathrm{~K}$ & Ruptured \\
\hline
\end{tabular}




\subsection{CREEP RUPTURE TEST RESULTS ON ALLOY 709}

The creep rupture life, minimum creep rate (MCR), elongation, and reduction of area are plotted in Fig. 10 and Fig. 11 for the 18 creep failure data points for ESR 1100 (heat number 58776-3RBB) generated at ORNL. These rupture tests were conducted at a temperature range of 600 to $925^{\circ} \mathrm{C}$ with a rupture life of up to $6333.5 \mathrm{~h}$. The lowest MCR is $4.2 \mathrm{E}-5 \% / \mathrm{h}$ at $875^{\circ} \mathrm{C}$ and $21 \mathrm{MPa}$, and the highest MCR is $0.0496 \% / \mathrm{h}$ at $925^{\circ} \mathrm{C}$ and $35 \mathrm{MPa}$. The ruptured specimens showed good creep ductility with elongation of between $19.8 \%$ to $80.3 \%$ and a reduction of area of between $27.2 \%$ and $81.5 \%$.

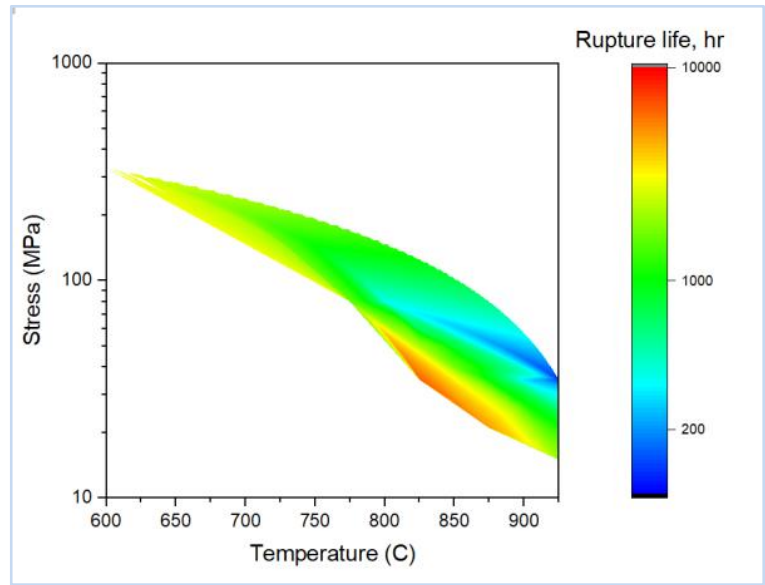

(a)

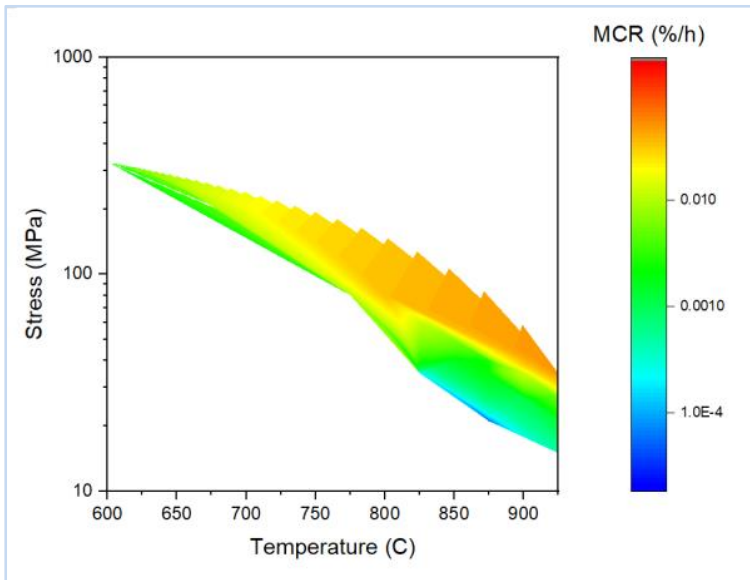

(b)

Fig. 10. Plots of the rupture life (a) and minimum creep rate (MCR) (b) for the 18 creep tests on ESR 1100 (heat number 58776-3RBB) at ORNL.

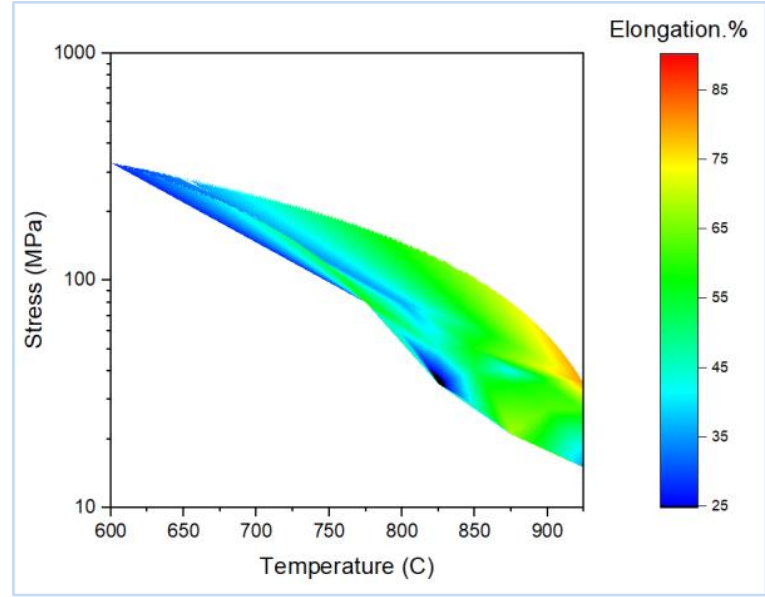

(a)

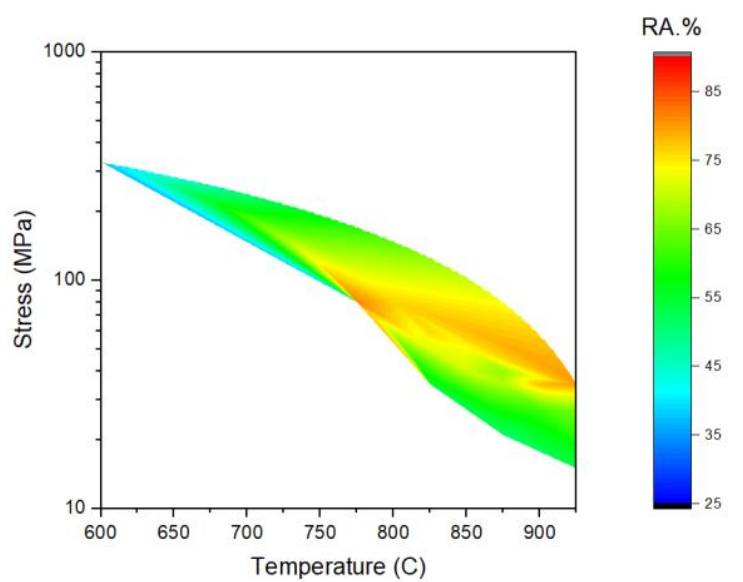

(b)

Fig. 11. Plots of the elongation (a) and reduction of area (b) for the 18 creep tests on ESR 1100 (heat number 58776-3RBB) at ORNL. 
At the time of this report, there are a total of 32 rupture data points generated by ORNL, ANL, and INL on ESR 1100 (heat number 58776-3RBB). To make a preliminary assessment of the creep resistance of the Alloy 709 material, these 32 rupture data points were compared with data for Nippon Steel NF709. The results are shown in Fig. 12. In this plot, the Larson-Miller equation for calculating the Larson-Miller Parameter (LMP) was based on the expression developed from Nippon Steel NF709 data:

$$
L M P=(\text { temperature }+273.15) *\left(16.6958+\log \left(t_{r}\right)\right)
$$

where temperate is in ${ }^{\circ} \mathrm{C}$ and rupture life, $t_{r}$ is in hours.

The rupture data for Nippon Steel NF709 are included in Fig. 12 for comparison purposes. The 32 data points for ESR 1100 were analyzed using Eq. (1) and plotted on this figure. The solid diamond symbols are from the 18 tests performed at ORNL. The results show that ESR 1100 is slightly weaker than Nippon Steel NF709 in terms of creep resistance, since all data points for ESR 1100 are to the left of those for Nippon Steel NF709, especially at the higher LMP values above 22,500. Additional rupture data are needed to fully assess the creep resistance of this first commercial heat of Alloy 709.

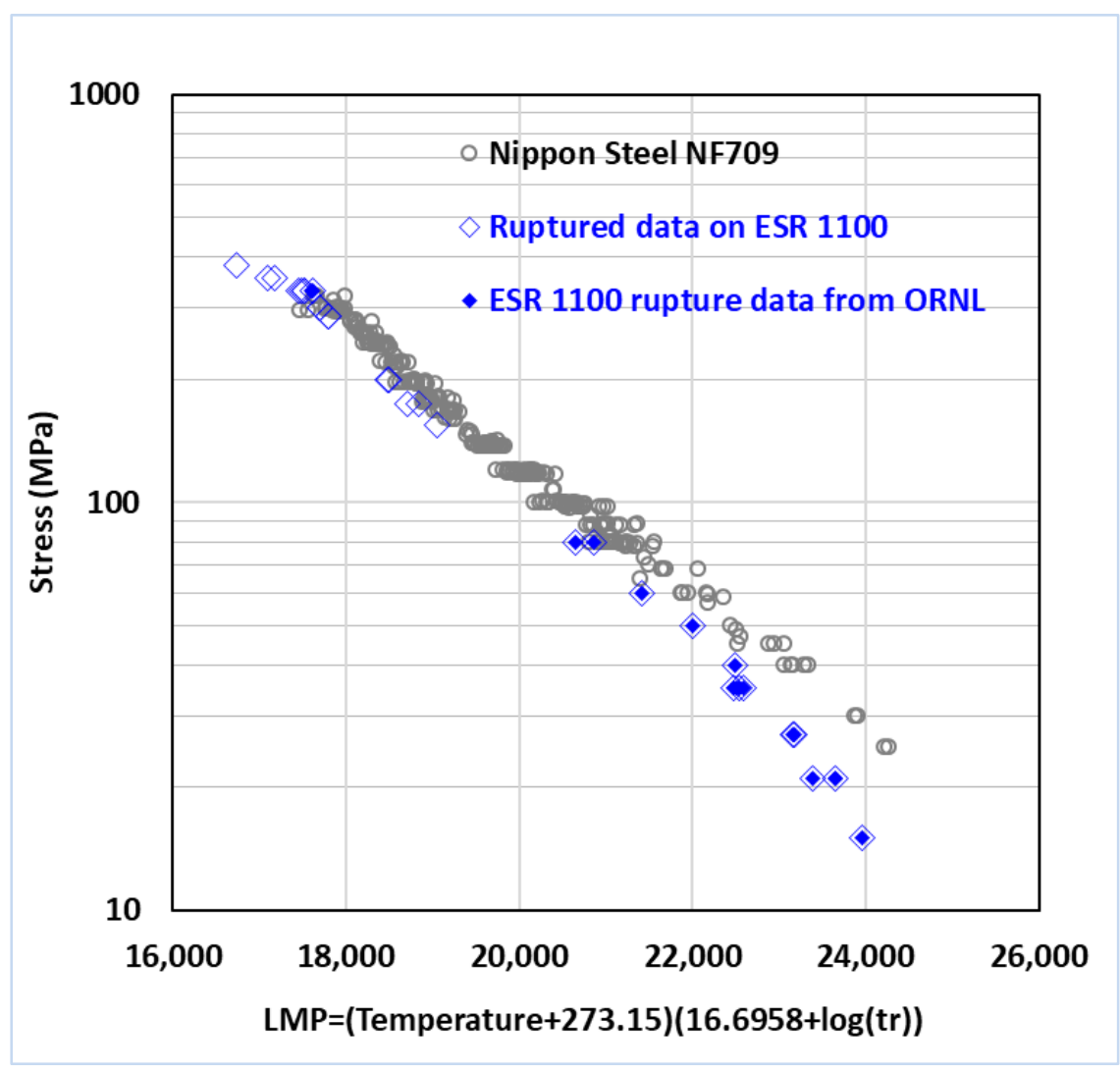

Fig. 12. Comparison of the ESR 1100 (heat number 58776-3RBB) creep rupture data with data for Nippon Steel NF709 on the LMP-stress plot.

\subsection{ADDITIONAL CONSIDERATIONS FOR CREEP RUPTURE TESTING}

A recent study of heat-treated Alloy 709 showed a significantly improved creep-fatigue cycle life but a certain degree of reduction in creep resistance (Rupp and McMurtrey 2020). To enable a comprehensive 
assessment of the high-temperature performance, it is recommended that a supplementary creep testing matrix for heat-treated Alloy 709 specimens be added to the creep Code Case testing. In preparation for this additional testing plan, a section of the ESR 1150 plate (heat number 58776-3RBC) was heat-treated using the same process $\left(775^{\circ} \mathrm{C}\right.$ for $\left.10 \mathrm{~h}\right)$ at ORNL in FY 2020, and a total of 19 of the creep specimens were machined and prepared for initiation of creep evaluation.

\section{FATIGUE AND CREEP FATIGUE CODE CASE TESTING ON ALLOY 709}

\subsection{FATIGUE TESTING PLAN}

The preliminary fatigue Code Case testing matrix was formed in FY 2019 in support of the development of fatigue design curves for Alloy 709 (Wang and Sham 2019). The plan was to generate fatigue design curves up to a maximum use temperature of $760^{\circ} \mathrm{C}$.

In FY 2020, fatigue Code Case testing was started at a temperature of $760^{\circ} \mathrm{C}$. The fatigue testing followed the ASTM E606-12 standard for conducting strain-controlled fatigue tests. The strain rate was controlled at $1 \mathrm{E}-3 \mathrm{~s}^{-1}$. A triangular loading waveform with a fully reversed profile, i.e., a loading ratio of $\mathrm{R}=-1$, was employed. The loading profile is shown schematically in Fig. 13.

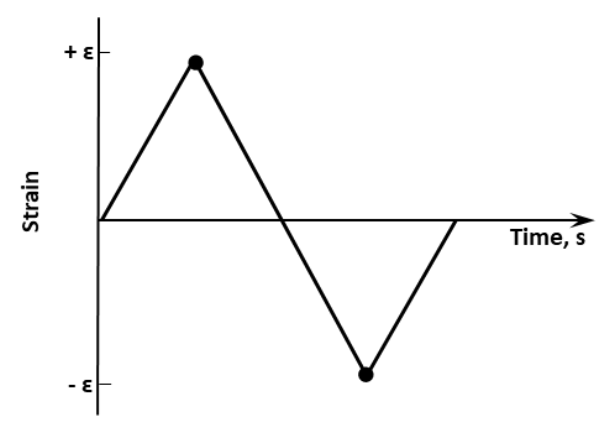

Fig. 13. Strain-controlled fatigue loading profile for one cycle.

\subsection{FATIGUE TEST RESULTS FOR ESR $1100 \mathrm{AT} 760^{\circ} \mathrm{C}$}

A total of 11 fatigue tests on ESR 1100 were carried out at $760^{\circ} \mathrm{C}$ in FY 2020. Failure data were generated at strain ranges of $3 \%, 2 \%, 1 \%, 0.6 \%, 0.4 \%, 0.3 \%$ and $0.25 \%$. One specimen was tested for fatigue at a very low strain range of $0.2 \%$ for $11,648,181$ cycles without failure.

The maximum and minimum stresses as a function of the applied cycles of these fatigue tests are plotted in Fig. 14 and Fig. 15. Two duplicate fatigue tests were conducted at the 1\%, 0.6\%, and 0.4\% strain ranges, and the results between the two duplicates were consistent. Cyclic hardening behavior was observed at the very beginnings of the applied cycles for all the fatigue tests at strain ranges of $0.3 \%$ and above, and the maximum and minimum stress levels remained saturated until the onset of failure initiation. In contrast, at a low strain range of $0.25 \%$, insignificant cyclic hardening was observed.

The fatigue testing parameter conditions and the cycles to failure are summarized in Table 7. The failure criteria based on the $25 \%$ maximum load drop were used to determine the cycles to failure. 


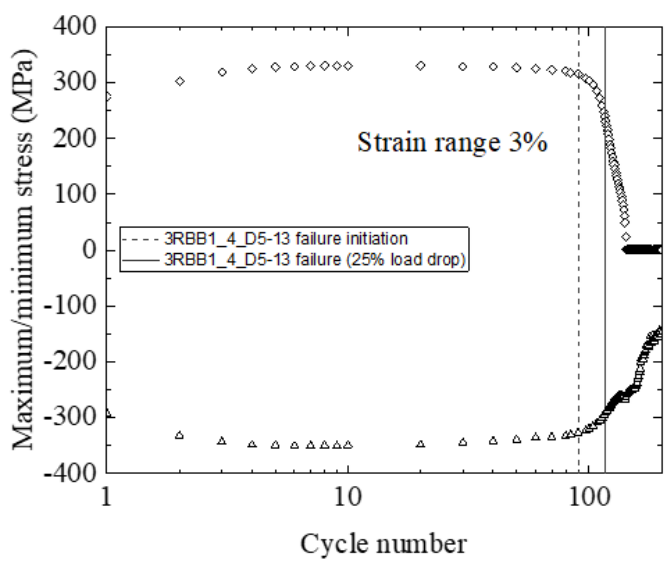

(a)

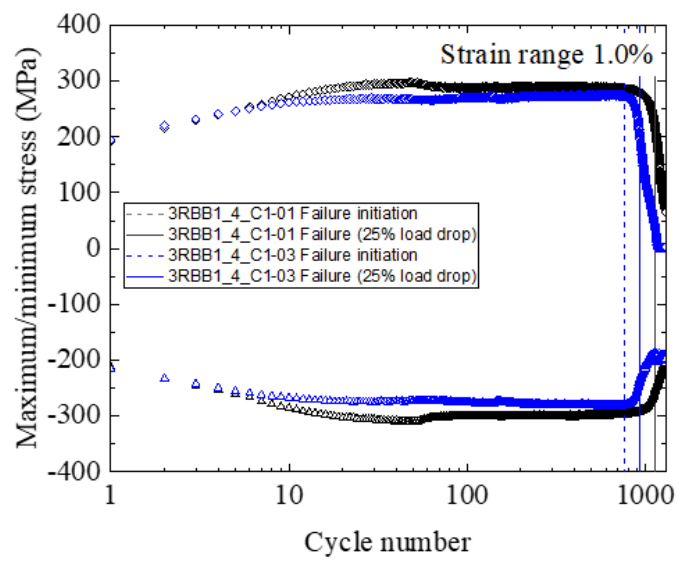

(c)

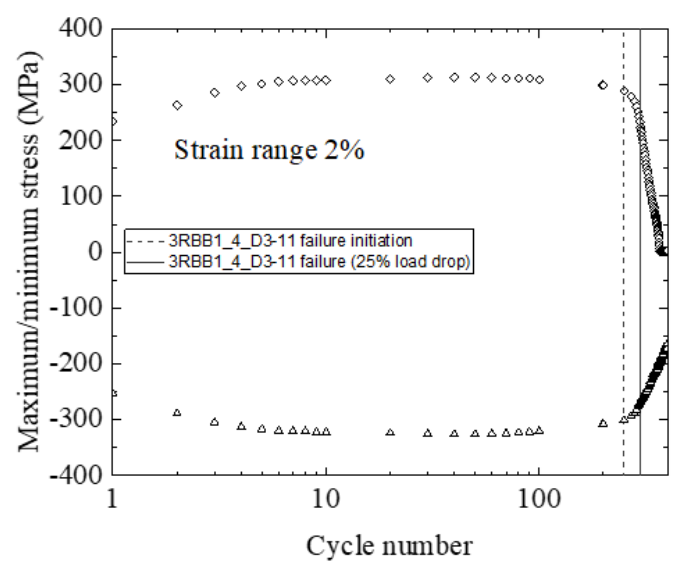

(b)

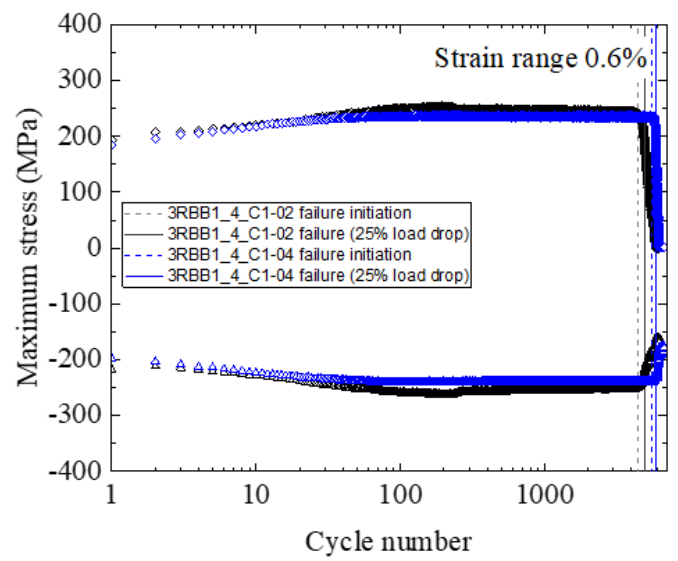

(d)

Fig. 14. Maximum and minimum stresses of fatigue tests on ESR 1100 (heat number 58776-3RBB) at strain ranges of $3 \%(a), 2 \%(b), 1 \%(c)$, and $0.6 \%$ (d) at $760^{\circ} \mathrm{C}$. 


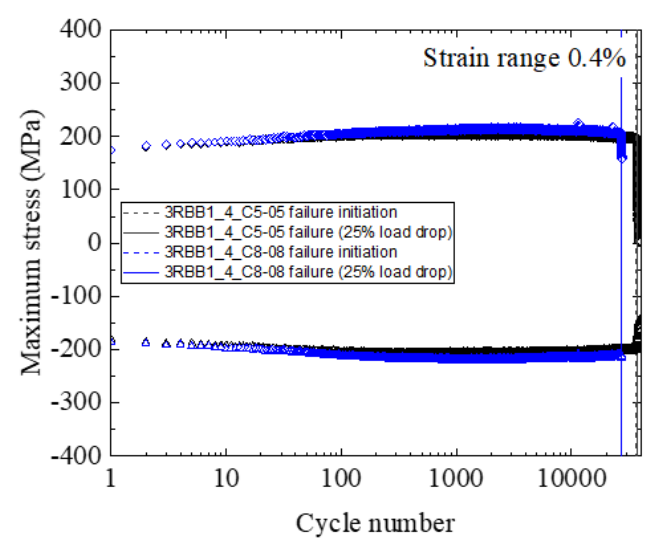

(a)

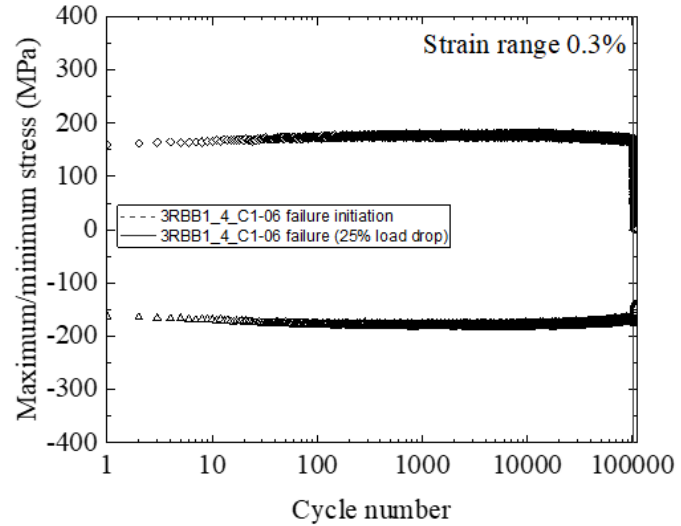

(b)

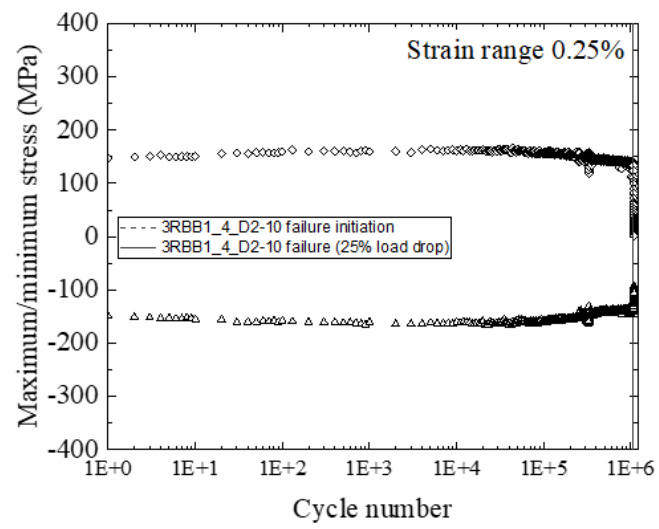

(c)

Fig. 15. Maximum and minimum stresses of fatigue tests on ESR 1100 (heat number 58776-3RBB) at strain ranges of $0.4 \%(a), 0.3 \%(b)$, and $0.25 \%$ (c) at $760^{\circ} \mathrm{C}$.

Table 7. Fatigue test results for ESR 1100 (heat number $58776-3 R B B$ ) at $760^{\circ} \mathrm{C}$.

\begin{tabular}{c|l|l|l}
\hline Test number & Specimen ID & \multicolumn{1}{|c}{$\begin{array}{c}\text { Strain range } \\
(\boldsymbol{\%})\end{array}$} & Cycles to failure* $^{*}$ \\
\hline 38777 & 3RBB1_4_D5-13 & 3.0 & 116 \\
\hline 38723 & 3RBB1_4_D3-11 & 2.0 & 300 \\
\hline 34339 & 3RBB1_4_C1-01 & 1.0 & 1,141 \\
\hline 34464 & 3RBB1_4_C3-03 & 1.0 & 927 \\
\hline 34371 & 3RBB1_4_C2-02 & 0.6 & 4,955 \\
\hline 34473 & 3RBB1_4_C4-04 & 0.6 & 5,921 \\
\hline 34492 & 3RBB1_4_C5-05 & 0.4 & 37,301 \\
\hline 39016 & 3RBB1_4_C8-08 & 0.4 & 27,407 \\
\hline 34523 & 3RBB1_4_C6-06 & 0.3 & 103,156 \\
\hline 38379 & 3RBB1_4_D2-10 & 0.25 & $1,074,000$ \\
\hline 34574 & 3RBB1_4_C7-07 & 0.2 & $>11,648,181 \dagger$ \\
\hline
\end{tabular}

Note:

* Failure criteria: $25 \%$ maximum load drop

$\dagger$ Specimen did not fail. The cycle number listed is the end of the test cycle. 


\subsection{FATIGUE TEST RESULTS FOR HEAT-TREATED ESR 1150 AT $760^{\circ} \mathrm{C}$}

Additional selected fatigue tests were performed at strain ranges of $3 \%, 2 \%, 1 \%$, and $0.6 \%$ on specimens from the heat-treated ESR 1150 plate at $760^{\circ} \mathrm{C}$ to enable a preliminary assessment of the effect of heat treatment on fatigue cycle life. Fig. 16 presents the maximum and minimum stresses as a function of the applied cycles for these four fatigue tests. Similar to the results for as-annealed ESR 1100, all test conditions show cyclic hardening behavior at the very beginnings of the applied cycles, followed by saturated maximum and minimum stresses until the onset of failure initiation. Table 8 summarizes the testing parameters and the cycles to failure of these four fatigue tests. When fatigue test results for heattreated ESR 1150 were compared with those for as-annealed ESR 1100, little or no difference was found for the fatigue failure cycles when both materials were fatigued under the same testing conditions.

However, comparing the maximum and minimum stresses under the same conditions (Fig. 14 and Fig. 16), the heat-treatment process has caused reductions in the peak stress values during cyclic loading.

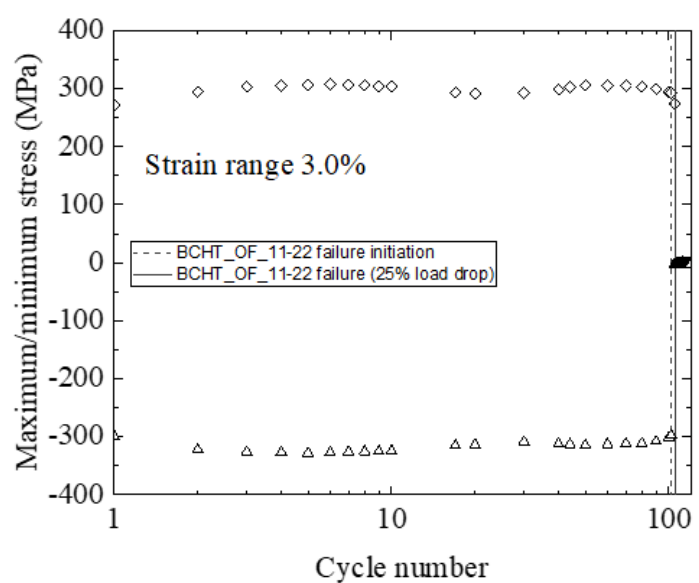

(a)

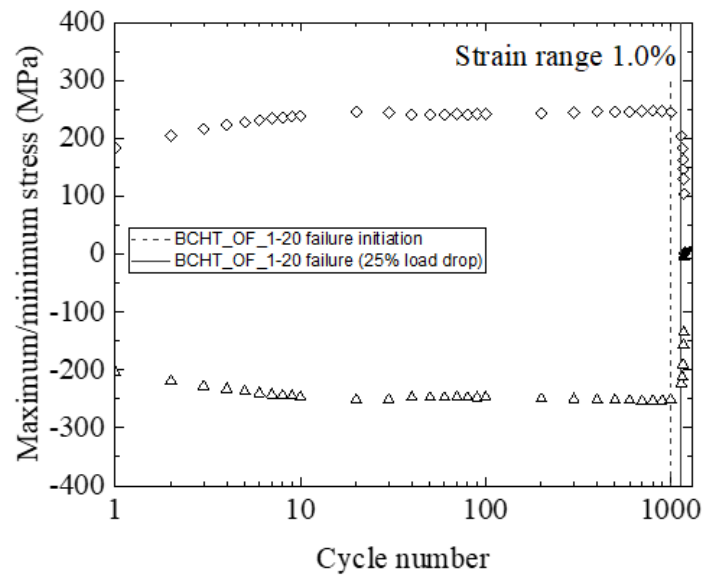

(c)

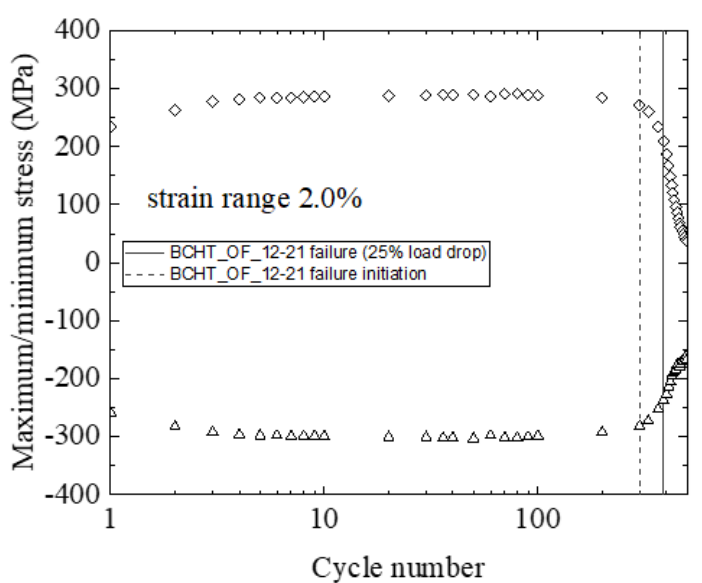

(b)

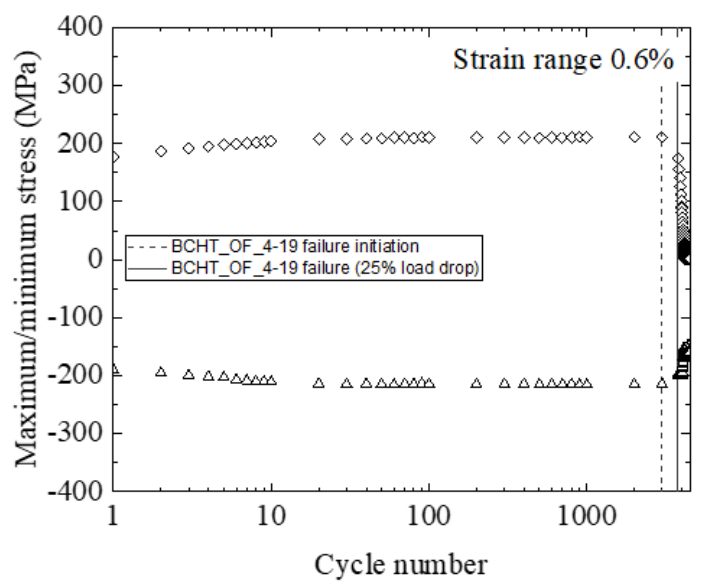

(d)

Fig. 16. Maximum and minimum stresses of fatigue tests on heat-treated ESR 1150 (heat number 58776$3 R B C)$ at strain ranges of $3 \%(a), 2 \%(b), 1 \%(c)$, and $0.6 \%$ (d) at $760^{\circ} \mathrm{C}$. 
Table 8. Fatigue test results of heat-treated ESR 1150 (heat number 58776-3RBC) at $760^{\circ} \mathrm{C}$.

\begin{tabular}{c|l|l|l}
\hline Test number & Specimen ID & \multicolumn{1}{|c}{$\begin{array}{c}\text { Strain range } \\
(\boldsymbol{\%})\end{array}$} & Cycles to failure* $^{*}$ \\
\hline 38793 & BCHT_OF_11-22 & 3.0 & 105 \\
\hline 38715 & BCHT_OF_12-21 & 2.0 & 387 \\
\hline 38706 & BCHT_OF_1-20 & 1.0 & 1,141 \\
\hline 38694 & BCHT_OF_4-19 & 0.6 & 3,762 \\
\hline
\end{tabular}

*Failure criteria: $25 \%$ maximum load drop.

\subsection{PRELIMINARY FATIGUE DESIGN CURVE OF ALLOY 709 AT $760^{\circ} \mathrm{C}$}

The fatigue test results for both ESR 1100 and heat-treated ESR 1150 were used to develop the preliminary fatigue design curve for Alloy 709 at $760^{\circ} \mathrm{C}$. A plot of strain range versus cycles to failure is presented in Fig. 17, along with the best-fit fatigue curve. Also shown in Fig. 17 is the preliminary fatigue design curve for Alloy 709 generated using the conventional method; i.e., it is the lesser of the two curves when a reduction factor of 2 on the strain range and a reduction factor of 20 on the number of cycles to failure are applied to the best-fit curve.

The preliminary fatigue design curve for Alloy 709 is compared with the ASME fatigue design curve of Alloy $800 \mathrm{H}$ at $760^{\circ} \mathrm{C}$ (from Figure HBB-T-1420-1C in ASME Section III Division 5 [ASME 2019b]) in Fig. 17. The result shows that the fatigue design curve of Alloy 709 is comparable to that of Alloy $800 \mathrm{H}$ at $760^{\circ} \mathrm{C}$.

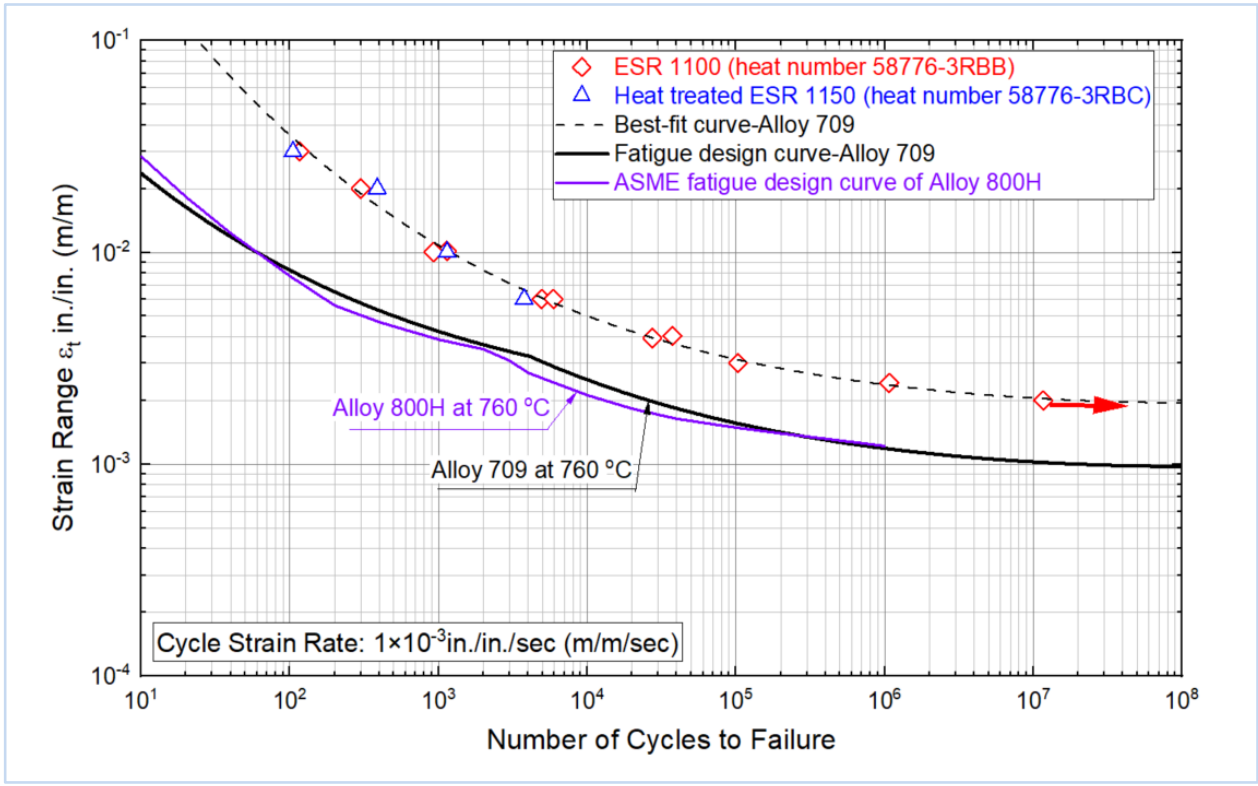

Fig. 17. Preliminary fatigue design curve of Alloy 709 at $760^{\circ} \mathrm{C}$.

\subsection{PRELIMINARY CREEP-FATIGUE TESTING PLAN ON ALLOY 709}

Creep-fatigue Code Case testing on heat-treated ESR 1150 is planned to generate data for developing the creep-fatigue interaction diagram. To be consistent with testing program conventions, creep-fatigue testing temperature will be based on US customary units and conducted at temperatures of 1200, 1300, 1400 , and $1500^{\circ} \mathrm{F}$. The equivalent temperatures in SI units are listed Table 9. The baseline strain rate will 
be at $1 \mathrm{E}-3 \mathrm{~s}^{-1}$ and various hold times will be applied to the peak amplitude. Two or three duplicate tests are planned for each condition. Creep-fatigue testing has been initiated at $1400^{\circ} \mathrm{F}$ and will continue in FY 2021.

Table 9. Preliminary creep-fatigue test matrix for Alloy 709.

\begin{tabular}{c|c|c|c}
\hline $\begin{array}{c}\text { Test temperature in US } \\
\text { customary units } \\
\left({ }^{\circ} \mathbf{F}\right)\end{array}$ & $\begin{array}{c}\text { Equivalent test } \\
\text { temperature in SI units } \\
\left({ }^{\circ} \mathbf{C}\right)\end{array}$ & $\begin{array}{c}\text { Fatigue and } \\
\text { creep-fatigue }\end{array}$ & $\begin{array}{c}\text { Hold time, } \\
\text { (seconds) }\end{array}$ \\
\hline RT & RT & \multirow{2}{*}{ Fatigue } & 0 \\
\hline 800 & 427 & \multirow{2}{*}{$\begin{array}{c}\text { Fatigue and creep- } \\
\text { fatigue }\end{array}$} & \multirow{2}{*}{600,1800, etc. } \\
\hline 1000 & 538 & 649 & \\
\hline 1200 & 704 & 760 & \\
\hline 1300 & 816 &
\end{tabular}

\section{SUMMARY}

The planned FY 2020 Code Case testing at ORNL in support of the ASME code qualification of Alloy 709 is summarized in this report. Baseline uniaxial tensile test results for heat-treated ESR 1150 (heat number 58776-3RBC) showed that the tensile properties met ASME SA-213 specifications (ASME 2019a) and were comparable to Nippon Steel NF709 Code Case data. Creep rupture data from 18 tests were generated for ESR 1100 (heat number 58776-3RBB) at ORNL. Currently, a total of 19 intermediate and long-term creep Code Case tests are running at ORNL. The preliminary assessment of the creep resistance based on the ruptured ESR 1110 test data indicate that this heat of Alloy 709 has slightly lower creep resistance than the Nippon Steel NF709 Code Case data. Supplementary creep Code Case testing on heat-treated ESR 1150 is also recommended. In addition, a preliminary fatigue design curve at $760^{\circ} \mathrm{C}$ was developed for Alloy 709, and the results show that the fatigue design curve of Alloy 709 is comparable to that of Alloy $800 \mathrm{H}$ at $760^{\circ} \mathrm{C}$

Fatigue, creep, and creep-fatigue experiments in support of the ASME code qualification of Alloy 709 will continue in FY 2021 at ORNL. 


\section{REFERENCES}

ASME SA-213 (2019a), Standard Specification for Seamless Ferritic and Austenitic Alloy-Steel Boiler, Superheater, and Heat-Exchanger Tubes, ASME Coiler and Pressure Vessel Code, Section II Materials, American Society of Mechanical Engineers, New York, NY (2019 Edition).

ASME (2019b), Boiler and Pressure Vessel Code, Section III Division 5, Rules for Construction of Nuclear Facility Components, Subsection HB Subpart B, American Society of Mechanical Engineers, New York, NY (2019 Edition).

ASTM E606/E606M-12, Standard Test Method for Strain-Controlled Fatigue Testing, ASTM International, West Conshohocken, PA, 2012, www.astm.org

ASTM E8-16, Standard Test Methods for Tension Testing of Metallic Materials, ASTM International, West Conshohocken, PA, 2018, www.astm.org

ASTM E21-17, Standard Test Methods for Elevated Temperature Tension Tests of Metallic Materials, ASTM International, West Conshohocken, PA, 2018, www.astm.org

M. D. McMurtrey (2018), Report on the FY18 Creep Rupture and Creep-Fatigue Tests on the First Commercial Heat of Alloy 709, INL/EXT-18-46140, Idaho National Laboratory, Idaho Falls, ID.

M. D. McMurtrey and R. Rupp (2019), Report on FY-19 Scoping Creep and Creep-Fatigue Testing on Heat Treated Alloy 709 Base Metal, INL/EXT-19-55502, Idaho National Laboratory, Idaho Falls, ID.

K. Natesan, X. Zhang, T.-L. Sham, and H. Wang (2017), Report on the Completion of the Procurement of the First Heat of Alloy 709, ANL-ART-89, Argonne National Laboratory, Lemont, IL, June 2017.

R. Rupp and M.D. McMurtrey (2020), Status of INL Aged A709 Mechanical Testing, INL/EXT-2059501, Idaho National Laboratory, Idaho Falls, ID.

H. Wang, C. S. Hawkins, E. C. Disney and J. L. Moser (2018), The Initiation of Long-Term Creep Rupture Tests on the First Alloy 709 Commercial Heat, ORNL/TM-2018/985, Oak Ridge National Laboratory, Oak Ridge, TN.

Y. Wang and T.-L. Sham (2019), Planned FY19 Creep and Fatigue Design Curve Testing of Alloy 709 Base Metal, ORNL/TM-2019/1303, Oak Ridge National Laboratory, Oak Ridge, TN.

Z. Zhang and T.-L. Sham (2019), FY19 Status Report on Creep Test Data on Commercial Heat of Alloy 709, ANL-ART-172, Argonne National Laboratory, Lemont, IL. 